\title{
Extracellular Alpha-Synuclein Oligomers Induce Parkin S-Nitrosylation: Relevance to Sporadic Parkinson's Disease Etiopathology
}

\author{
Anna Wilkaniec ${ }^{1}$ - Anna M. Lenkiewicz ${ }^{1}$ • Grzegorz A. Czapski ${ }^{1}$ Henryk M. Jęśko ${ }^{1}$ - Wojciech Hilgier ${ }^{2}$. \\ Robert Brodzik ${ }^{3}$ - Magdalena Gąssowska-Dobrowolska ${ }^{1} \cdot$ Carsten Culmsee $^{4} \cdot$ Agata Adamczyk $^{1}$ (I)
}

Received: 26 October 2017 / Accepted: 11 April 2018 / Published online: 21 April 2018

(C) The Author(s) 2018

\begin{abstract}
$\alpha$-Synuclein (ASN) and parkin, a multifunctional E3 ubiquitin ligase, are two proteins that are associated with the pathophysiology of Parkinson's disease (PD). Excessive release of ASN, its oligomerization, aggregation, and deposition in the cytoplasm contribute to neuronal injury and cell death through oxidative-nitrosative stress induction, mitochondrial impairment, and synaptic dysfunction. In contrast, overexpression of parkin provides protection against cellular stresses and prevents dopaminergic neural cell loss in several animal models of PD. However, the influence of ASN on the function of parkin is largely unknown. Therefore, the aim of this study was to investigate the effect of extracellular ASN oligomers on parkin expression, $S$-nitrosylation, as well as its activity. For these investigations, we used rat pheochromocytoma (PC12) cell line treated with exogenous oligomeric ASN as well as PC12 cells with parkin overexpression and parkin knock-down. The experiments were performed using spectrophotometric, spectrofluorometric, and immunochemical methods. We found that exogenous ASN oligomers induce oxidative/nitrosative stress leading to parkin $S$ nitrosylation. Moreover, this posttranslational modification induced the elevation of parkin autoubiquitination and degradation of the protein. The decreased parkin levels resulted in significant cell death, whereas parkin overexpression protected against toxicity induced by extracellular ASN oligomers. We conclude that lowering parkin levels by extracellular ASN may significantly contribute to the propagation of neurodegeneration in PD pathology through accumulation of defective proteins as a consequence of parkin degradation.
\end{abstract}

Keywords Alpha-synuclein $\cdot$ Parkin $\cdot$ Parkinson's disease $\cdot S$-nitrosylation

\section{Introduction}

Parkin and alpha-synuclein (ASN) are two major proteins associated with the pathophysiology of Parkinson's disease

Anna Wilkaniec and Anna M. Lenkiewicz have contributed equally to this study.

Electronic supplementary material The online version of this article (https://doi.org/10.1007/s12035-018-1082-0) contains supplementary material, which is available to authorized users.

Agata Adamczyk

aadamczyk@imdik.pan.pl

1 Department of Cellular Signalling, Mossakowski Medical Research Centre, Polish Academy of Sciences, Pawińskiego 5 Street, 02-106 Warsaw, Poland

2 Department of Neurotoxicology, Mossakowski Medical Research Centre, Polish Academy of Sciences, Pawińskiego 5 Street, 02-106 Warsaw, Poland

3 BLIRT S.A., Trzy Lipy 3/1.38, 80-172 Gdańsk, Poland

4 Institute of Pharmacology and Clinical Pharmacy, University of Marburg, 35043 Marburg, Germany
(PD). Recessive mutations in the autosomal parkin gene $P A R K 2$ are the most common causes of familial early onset $\mathrm{PD}$, while dominant mutations in the autosomal ASN gene cause late onset PD [1]. In sporadic PD, ASN accumulates into cytosolic inclusions called Lewy bodies (LBs) [2]. Previous investigations revealed that the toxicity of overproduced and aggregated ASN is mainly attributed to the formation of "toxic ASN oligomers." Those heterogeneous and till now poorly characterized group of ASN conformers may negatively impact cells by inducing oxidativenitrosative stress, mitochondrial alterations, endoplasmic reticulum stress, proteasomal defects, synaptic dysfunction, and neuroinflammation [3-5]. A growing body of evidence further suggests that ASN may be able to self-propagate between neurons, in a prion-like manner, which may play a pivotal role in PD pathology. ASN may also act as a trigger of neurodegenerative processes associated with oligomerization of other amyloidogenic proteins, including amyloid-beta peptide $(\mathrm{A} \beta)$ [6] or through damage of protein degradation systems $[7,8]$. On the contrary, the role of parkin in sporadic PD is explained mainly through functional inactivation due to nitrosative and 
oxidative stress [9-12] or altered dopamine metabolism [13]. This seems to be particularly significant to PD pathogenesis, since the major function of parkin as an E3-ubiquitin ligase is involved in ensuring the quality control of protein conformation and mitochondrial function [14-17].

Despite the lack of a genetic link between parkin and ASN, pathological interaction between ASN and parkin in sporadic PD has emerged as an important trigger of neurodegenerative processes [1]. Based on the genetic evidence and the established role of parkin as a ubiquitin ligase, the scientific interest was initially focused on investigating the link of parkin alterations and proteasomal dysfunction to ASN accumulation [7, 18]. However, it was demonstrated that ubiquitinproteasome system (UPS) contributes to ASN turnover mainly in physiological conditions and only the glycosylated form of ASN is a substrate for parkin's ubiquitin ligase activity in human brain tissue [18-20]. Further, subsequent studies showed that proteasomal degradation of ASN does not require the ubiquitination of this protein [21]. Interestingly, in pathological conditions, the increased intracellular ASN burden is recruited mainly into the autophagy-lysosomal pathway instead of UPS [20]. These observations indicated that aberrant ASN is less likely the direct substrate for parkin E3 ligase activity, which corresponds to studies showing that loss of parkin function (via mutations) is usually not associated with LBs [22]. Intriguingly, one recent publication demonstrated that neuroprotective properties of parkin activation are mediated by autophagic degradation of ASN [23]. Parkin also reduced the level of phosphorylated ASN in immortalized dopaminergic cells and attenuated ASN-induced glia activation [24]. Moreover, when parkin is down-regulated, it induces increased ASN secretion into the blood [23]. Since ASN oligomers display prion-like properties, including entry into naïve neurons and the ability to selfinteract and aggregate [25], thus it might be probable that the proper maintenance of parkin activity might protect against the toxic spread of ASN. Since, as parkin often co-localizes with ASN inclusions in PD patient's brain tissue [3, 26], and many posttranslational modifications of parkin are associated with the toxic conditions evoked by ASN, it is proposed that ASN may affect parkin catalytic activity, solubility, substrate selection, and subcellular localization. Therefore, we aimed at exploring pathological interactions between ASN and parkin, especially the role of extracellular ASN in deregulating parkin levels, posttranslational modifications, and activities.

\section{Materials and Methods}

\section{Reagents}

Dulbecco's modified Eagle's medium (DMEM), fetal bovine serum (FBS), horse serum (HS), penicillin, streptomycin, G418, L-glutamine, dimethyl sulfoxide (DMSO), $N$ - acetylcysteine (NAC), $N$-w-nitro-L-arginine (NNLA), polyethylenoimine (PEI), collagen, pluronic, probenecid, Hank's balanced salt solution (HBSS), Hepes, ethanol, phosphate-buffered saline (PBS), Thioflavin-T, sodium nitroprusside (SNP), D184 (Deano), TRI reagent, deoxyribonuclease I (DNase I), 2'-(4-hydroxyphenyl)-5-(4-methyl-1piperazinyl)-2,5'-bi-1H-benzimidazole trihydrochloride hydrate, bis Benzimide (Hoechst 33258), 3-(4,5-dimethyl-2tiazolilo)-2,5-diphenyl-2H-tetrazolium bromide (MTT), Trisbuffered saline, $\mathrm{NaCl}$, Tween 20, 2,2',2", 2"'-(ethane-1,2diyldinitrilo)tetraacetic acid (EDTA), sodium fluoride (NaF), sodium orthovanadate $\left(\mathrm{Na}_{3} \mathrm{VO}_{4}\right)$, sodium pyrophosphate $\left(\mathrm{NaP}_{2} \mathrm{O}_{3}\right)$, benzamidine, Nonidet $\mathrm{P}-40$, phenylmethylsulfonyl fluoride (PMSF), N-p-Tosyl-L-phenylalanine chloromethyl ketone (TPCK), soybean trypsin inhibitor (STI), aprotinin, leupeptin, and bovine serum albumin (BSA) were obtained from Sigma-Aldrich (St. Louis, MO, USA). Cell Lysis Buffer $(10 \times)$ was obtained from Cell Signaling (Beverly, MA, USA).

\section{Preparation of ASN Oligomers and Protofibrils}

Human recombinant lyophilized ASN was obtained from rPeptide (Bogart, GA, USA). ASN oligomers were prepared according to Danzer et al. [27] with modifications. Briefly, lyophilized ASN was dissolved to $7 \mu \mathrm{M}$ concentration in $50 \mathrm{mM}$ sodium phosphate buffer (PB), $\mathrm{pH} 7.0$, containing $20 \%$ ethanol. After $4 \mathrm{~h}$ of shaking (1000 rpm, room temperature; RT), oligomers were re-lyophilized and re-suspended with one-half of starting volume of $50 \mathrm{mM} \mathrm{PB}, \mathrm{pH} 7.0$, containing $10 \%$ ethanol. This was followed by stirring, with open lids to evaporate residual ethanol, for $24 \mathrm{~h}$ at RT under the sterile hood. Concentration of obtained ASN oligomers was then measured using NanoDrop 2000 spectrophotometer (Thermo Scientific). For preparation of protofibrils, ASN was dissolved in PBS at a concentration of $100 \mu \mathrm{M}$ and aggregated for 14 days at $37^{\circ} \mathrm{C}$.

\section{Thioflavin-T Assay}

ASN oligomer and aggregate formation was monitored with Thioflavin-T binding fluorescence. Mixture of ASN species with Thioflavin-T $(20 \mu \mathrm{M})$ was prepared in $50 \mathrm{mM}$ phosphate buffer $(50 \mu \mathrm{l})$. The sample was kept for $5 \mathrm{~min}$ at RT and protected from light. Emission was measured at $483 \mathrm{~nm}$ with an excitation at $450 \mathrm{~nm}$ using fluorescence spectrophotometer (FLUOstar Omega; BMG LABTECH, Ortenberg, Germany).

\section{Transmission Electron Microscopy}

Sample preparation for transmission electron microscopy (TEM) was performed at RT. Typically, $5 \mu$ of ASN species 
was applied to the copper mesh covered by formvar and incubated for $1 \mathrm{~min}$. Subsequently, the grid was washed by three drops of deionized water and stained with $2 \%$ uranyl acetate for $1 \mathrm{~min}$. The reagent was rinsed with deionized water and dried in the air grid. The analysis was made in the transmission electron microscope Zeiss LEO.

\section{Atomic Force Microscopy}

Sample preparation for atomic force microscopy (AFM) was performed at RT. Typically, 3-6 $\mu$ l of different ASN species diluted in corresponding buffers to a working concentration of $1 \mu \mathrm{M}$ were applied to a freshly cleaved muscovite mica substrate (Ted Pella, Redding, CA) and incubated for $1 \mathrm{~min}$. The mica surface was then rinsed with $7-200 \mu$ l of doubleprocessed tissue culture water (Sigma-Aldrich, St. Louis, MO, USA) to remove salts and loosely bound proteins. AFM images were recorded on a MultiMode ${ }^{\mathrm{TM}} \mathrm{SPM}$ (Digital Instruments, Santa Barbara, CA) equipped with an E-Scanner using etched silicon NanoProbes (model RTESP; Veeco Instruments, Mannheim, Germany). All measurements were performed in the tapping mode with scan rates of $0.5 \mathrm{~Hz}$. Images were processed using NanoScope software (Digital Instruments).

\section{Cell Culture}

The studies were carried out using rat pheochromocytoma (PC12) cells. PC12 cells were cultured in DMEM supplemented with $10 \%$ heat-inactivated FBS, $5 \%$ heat-inactivated HS, 50 units $/ \mathrm{ml}$ penicillin, and $50 \mu \mathrm{g} / \mathrm{ml}$ streptomycin and Lglutamine at $37{ }^{\circ} \mathrm{C}$ in a humidified incubator in $5 \% \mathrm{CO}_{2}$ atmosphere.

\section{Cellular Treatment}

PC12 cells were seeded into 60- or 35-mm culture dishes, 24well or 96-well plates (coated with $0.1 \%$ PEI or rat tail collagen), and the growth medium was changed into a low-serum medium (DMEM supplemented with 2\% FBS, $1 \%$ penicillin/ streptomycin, and $1 \%$ L-glutamine). HBSS or other media appropriate for the particular procedure were also used. Then, the cells were treated with exogenous ASN oligomers $(5 \mu \mathrm{M})$, NAC $(100 \mu \mathrm{M}$; dissolved in water), and NNLA $(100 \mu \mathrm{M}$; dissolved in water) for appropriate time points. Suitable solvent was added to respective controls.

\section{siRNA-Mediated Parkin Knock-Down}

For RNA interference, PC12 cells were transfected with appropriate siRNA: PARK-2 (L-090709-02; Dharmacon) or control (D-001810-10-05; Dharmacon) using Lipofectamine RNAiMAX (Invitrogen) according to the manufacturer's protocol. The expression of parkin in transfected cells was then examined by RT-PCR and Western blot.

\section{Stable, Constitutive Overexpression of Parkin in PC12 Cells}

The sequence encoding human wild-type parkin was subcloned into AscI/PacI sites of pcDNA4.3Asc vector. The construct was evaluated first using AscI/PacI restriction analysis and then with Western blot on extracts of transiently transfected $\mathrm{CHO}$ cell with antibodies against parkin (Santa Cruz, SC-32282).

PC1 2 cells were electroporated at $5 \times 10^{6}$ per cuvette (BioRad Gene Pulser Xcell) with $10 \mu \mathrm{g}$ of DNA ( $0.5 \mathrm{ml}$ medium), using VWR cuvettes with $4 \mathrm{~mm}$ gap and one $30 \mathrm{~ms}$ pulse of $220 \mathrm{~V}$. The cells were plated in culture medium and propagated with one medium change until reaching $90 \%$ confluency. Then, selection was started using G418 (30 $\mu \mathrm{g} / \mathrm{ml}$ initial concentration, gradually increased to $100 \mu \mathrm{g} / \mathrm{ml}$ ). After the cells accumulated, clonal selection was performed.

\section{Fluorometric Measurements of Changes in $\left[\mathrm{Ca}^{2+}\right]_{\mathrm{i}}$ ?}

Changes in intracellular $\mathrm{Ca}^{2+}\left(\left[\mathrm{Ca}^{2+}\right]_{\mathrm{i}}\right)$ concentration in PC12 cells were monitored using the fluorescent calciumsensitive probe Fluo-4. Its acetoxymethyl ester derivative, Fluo-4AM, easily penetrates plasma membranes, and inside the cells it is cleaved by esterases to Fluo-4, which becomes highly fluorescent after binding with $\mathrm{Ca}^{2+}$. The procedure is essentialy as described previously by Wilkaniec et al. [28]. PC12 cells were seeded onto collagen-coated 96-well dark plates at the density of $1.4 \times 10^{5}$ cells $/ \mathrm{ml}$. After $24 \mathrm{~h}$, the cells were loaded with $10 \mu \mathrm{M}$ Fluo-4AM supplemented with $0.02 \%$ Pluronic ${ }^{\circledR}$ F68 for 60 min at $37^{\circ} \mathrm{C}$ in a standard HBSS. The cells were washed three times with HBSS and, to ensure complete $\mathrm{AM}$ ester hydrolysis, kept for $30 \mathrm{~min}$ at $37{ }^{\circ} \mathrm{C}$ in the dark. After a second washing, the fluorescence was measured using a microplate reader FLUOstar Omega (Ortenberg, Germany) set at $485 \mathrm{~nm}$ excitation and $538 \mathrm{~nm}$ emission wavelengths. After determining the baseline fluorescence of the cells incubated in HBSS, the changes in fluorescence after the addition of the test compounds were recorded every $15 \mathrm{~s}$ for $5 \mathrm{~min}$. This 5 -min treatment did not have any significant impact on cell viability. The results of fluorescence measurements are presented as percent changes in fluorescence intensity relative to the basal level versus duration of measurement $(\% F / F 0)$. To quantify the change in the dynamics of the $\mathrm{Ca}^{2+}$ responses, the area under the curve (AUC) was calculated as a measure for the increase in intracellular $\mathrm{Ca}^{2+}$. 


\section{HPLC Measurements of Arginine and Its Metabolites}

Cells were scraped in $1 \mathrm{ml}$ of PBS, spun down, and resuspended in $100 \mu \mathrm{l}$ of $45 \mathrm{mM}$ phosphate buffer $\mathrm{pH} 6.2$ with $10 \%$ acidic methanol. After sonication $(10$ cycles $3 \mathrm{~s}$ each, $10 \%$ power setting, BioLogics $150 \mathrm{~V} / \mathrm{T}$ ), the material was centrifuged for $10 \mathrm{~min}$ at $13,000 \times \mathrm{g}$. The protein pellet was re-suspended in $0.5 \mathrm{ml} 1 \mathrm{M} \mathrm{NaOH}$ for protein measurement (Bradford). Supernatant was stored at $-20{ }^{\circ} \mathrm{C}$ and used for HPLC amino acid analysis with fluorescence detection after derivatization in a timed reaction with $o$ phtalaldehyde plus mercaptoethanol, as described by Jesko et al. [29]. Derivatized samples $(25 \mu \mathrm{l})$ were injected on to a $150 \times 4.6-\mathrm{mm} 5 \mu$ Hypersil Gold BDS C18 column with a mobile phase of $50 \mathrm{mM}$ phosphate buffer $\left(\mathrm{KH}_{2} \mathrm{PO}_{4}\right.$ $/ \mathrm{K}_{2} \mathrm{HPO}_{4}$ ) containing $10 \% v / v$ methanol, $\mathrm{pH} 6.2$ (solvent $\mathrm{A})$, and methanol (solvent B).

\section{Measurement of Intracellular Free Radical Level}

Measurement of the free radicals level was carried out using fluorescent indicator 2'7'-dichlorofluorescein diacetate (DCFH-DA) (Cayman Chemical Company), as described previously [6]. DCFH-DA is intracellularly deacetylated to $2^{\prime} 7^{\prime}$ dichlorofluorescin (DCFH) and then oxidized by hydrogen peroxide to a fluorescent compound, 2'7'-dichlorofluorescein (DCF). PC12 cells were incubated in DCFH-DA $(10 \mu \mathrm{M})$ solution in HBSS with $20 \mathrm{mM}$ Hepes ( $\mathrm{pH}$ 7.4) and $0.02 \%$ Pluronic for $50 \mathrm{~min}$ at $37^{\circ} \mathrm{C}$ in the dark. Then, the cells were washed three times and the DCF fluorescence was measured using a microplate reader FLUOstar Omega (Ortenberg, Germany) at $485 \mathrm{~nm}$ excitation and $538 \mathrm{~nm}$ emission wavelengths. After determining the baseline fluorescence of the cells incubated in HBSS, the changes in fluorescence after the addition of the test compounds were recorded every 1 for $8 \mathrm{~h}$. The results of fluorescence measurements are presented as percent of corresponding control.

\section{Determination of Intracellular Nitric Oxide Level in Cells}

Measurement of the nitric oxide level was carried out using fluorescent indicator 4,5-diaminofluorescein diacetate (DAF2 DA) (Cayman Chemical Company). DAF-2 DA is oxidized by nitric oxide to a fluorescent compound, DAF-2. PC12 cells were incubated $20 \mathrm{~min}$ at $37^{\circ} \mathrm{C}$ in the dark with $10 \mu \mathrm{M}$ DAF$2 \mathrm{DA}$ in the presence of $0.02 \%$ Pluronic. The cells were washed with Pluronic-supplemented Hanks' balanced salt solution with $20 \mathrm{mM}$ Hepes (pH 7.4) and kept for $30 \mathrm{~min}$ at $37^{\circ} \mathrm{C}$ in the dark. After a second washing, the fluorescence was measured using a microplate reader FLUOstar Omega (Ortenberg, Germany) set at $488 \mathrm{~nm}$ excitation and $530 \mathrm{~nm}$ emission wavelengths. After determining the baseline fluorescence of the cells incubated in HBSS, the changes in fluorescence after the addition of the test compounds were recorded every 1 for $8 \mathrm{~h}$. The results of fluorescence measurements are presented as percent of corresponding control.

\section{Determination of Nitric Oxide Level in Cell-Free System}

Measurement of the nitric oxide level was carried out using fluorescent indicator DAF-2 DA (Cayman Chemical Company). Mixture of methanol, $2.5 \mathrm{mM}$ DAF-2 DA, and $2 \mathrm{M} \mathrm{KOH} \mathrm{(1:1:0.5)} \mathrm{was} \mathrm{kept} \mathrm{in} \mathrm{darkness} \mathrm{at} \mathrm{RT} \mathrm{for} 1 \mathrm{~h}$. Then, $\mathrm{HCl}$ was added to neutralize the mixture $(\mathrm{pH} 7.0)$. NAC $(100 \mu \mathrm{M})$, NNLA $(100 \mu \mathrm{M})$, SNP $(500 \mu \mathrm{M})$, Deano $(500 \mu \mathrm{M})$, water, and DAF-2 DA $(10 \mu \mathrm{M})$ were added to selected well. The fluorescence of DAF-2 was measured by $8 \mathrm{~h}$ using a fluorescence spectrophotometer (FLUOstar Omega; BMG LABTECH, Ortenberg, Germany) with excitation at $488 \mathrm{~nm}$ and emission at $530 \mathrm{~nm}$.

\section{Cytosolic Redox Environment}

To investigate changes in cytosolic redox environment, $\mathrm{PC} 12$ cells were transfected with a plasmid coding for a redoxsensitive green fluorescent protein (roGFP in pEGFP-N1). In an oxidized environment, the absorption increases at short wavelengths $(375 \mathrm{~nm})$ at the expense of absorption at longer wavelengths $(500 \mathrm{~nm})$. The fluorescence ratio indicates oxidation/reduction as described previously by Cannon and Remington [30]. PC12 cells were transfected using electroporation (Neon Transfection System) in $100 \mu$ l volume containing $1.4 \times 10^{6}$ cells and $20 \mu \mathrm{g}$ DNA, at manufacturer's PC12optimized pulse parameters (ThermoFisher Scientific). Cells were plated in four replicates onto 96-well plates at a density of $1.5 \times 10^{4}$ cells/well in standard culture medium less antibiotics and kept overnight at $37{ }^{\circ} \mathrm{C}$ in $5 \% \mathrm{CO}_{2}$. After 24-h treatment with oligomeric ASN, cells were washed twice with PBS and placed in a Hank's buffer. The ratio $375 \mathrm{~nm} / 500 \mathrm{~nm}$ was measured using multiplate reader Infinite M1000 PRO (TECAN). An increase of the ratio indicates a more oxidized environment.

\section{Quantitative Real-Time Polymerase Chain Reaction}

The total RNA isolation was performed according to the procedure developed by Chomczyński, using TRI Reagent ${ }^{\circledR}$ (cat. T9424) from Sigma-Aldrich, following the manufacturer's protocol. Digestion of DNA contamination was performed using DNase I according to the manufacturer's protocol (Sigma-Aldrich, St. Louis, MO, USA). RNA quantity and quality were controlled by spectrophotometric analysis and gel electrophoresis. A reverse transcription was performed by using the high capacity cDNA reverse transcription kit 
according to the manufacturer's protocol (Applied Biosystems, Foster City, CA, USA). Quantitative real-time PCR was performed with TaqMan Universal PCR Master Mix (Applied Biosystems, Foster City, CA, USA) or Power SYBR Green PCR Master Mix (Applied Biosystems, Foster City, CA, USA) and detected by a Real-Time PCR System on an ABI PRISM 7500 apparatus (Thermo Fisher Scientific, Waltham, MA, USA) using the commercially available TaqMan ${ }^{\circledR}$ Gene Expression Assays (Actb Rn01412977_g1; Park-2 Rn00571787_m1; Gpx1Rn00577994_g1, Txnrd1 Rn01503798_m1) or selected primer pairs (forward/reverse): Sod 2 5'-CGCTGGCCAAGGGAGAT-3'/5'-CCCC GCCATTGAACT TCA - 3'; Gad $d 455^{\prime}-\mathrm{CGGG}^{\prime}$ ACCGGGACATCTC-3'/5'-GGCACTTCAGGGCT TTCTCTT-3'; $P r d x 3$ 5'-GTGGATTCCCACTTCAGTCA TCT-3'/5'-GTTCATGTGGCCCAAACCA-3'; and Top $1 m t$ 5'-CGACTGGCAGAAGGAAATGAC-3'/5'-AGTG CCTATGGATCTCCGAGAA-3' for SYBR Green assay. Actb was used in the analysis as a reference gene. A standard two-step PCR amplification was performed, with a melting step at $95{ }^{\circ} \mathrm{C}$ for $15 \mathrm{~s}$ and annealing and elongation at $60{ }^{\circ} \mathrm{C}$ for $1 \mathrm{~min}$, for 40 cycles. For SYBR Green assay, after PCR amplification, a first derivative melting curve analysis was conducted to confirm the specificity of the PCR. The relative levels of target mRNA, normalized to an endogenous reference and relative to a calibrator, were calculated by $2^{-\Delta \Delta C T}$ formula.

\section{Parkin Co-Immunoprecipitation}

The cells were washed three times with ice-cold PBS and lysed in cold lysis buffer containing $50 \mathrm{mM}$ Tris- $\mathrm{HCl}(\mathrm{pH}$ 7.4), $0.25 \mathrm{M} \mathrm{NaCl}, 0.1 \% v / v$ Nonidet P-40, 5 mM EDTA, $50 \mathrm{mM} \mathrm{NaF}, 1 \mathrm{mM} \mathrm{Na} \mathrm{VO}_{4}, 1 \mathrm{mM} \mathrm{Na} \mathrm{P}_{2} \mathrm{O}_{7}, 10 \mathrm{mM}$ benzamidine, $50 \mu \mathrm{g} / \mathrm{ml}$ PMSF, $10 \mu \mathrm{g} / \mathrm{ml}$ TPCK, $10 \mu \mathrm{g} / \mathrm{ml}$ STI, $1 \mu \mathrm{g} / \mathrm{ml}$ aprotinin, and $1 \mu \mathrm{g} / \mathrm{ml}$ leupeptin. Protein levels were determined using the Bradford method, and $1 \mathrm{mg}$ of protein lysate was combined with $25 \mu$ l Protein GDynabeads (Novex, Life Technologies) pre-incubated with mouse anti-parkin $(1 \mu \mathrm{g})$ antibody followed by overnight incubation by rotation at $4{ }^{\circ} \mathrm{C}$. Cell lysates were rotated with antibody-bound Dynabeads at $4{ }^{\circ} \mathrm{C}$ for $1 \mathrm{~h}$, and the obtained complexes were sequentially washed three times with IP buffer. Immunoprecipitates were eluted by heating at $95{ }^{\circ} \mathrm{C}$ for 5 min in $2 \times$ Laemmli sample buffer and separated on SDS/ PAGE gels, transferred to nitrocellulose membranes at $100 \mathrm{~V}$, and subjected to Western blot analysis.

\section{Western Blot Analysis}

The cells were washed twice with ice-cold PBS and lyzed in Cell Lysis Buffer $(1 \times)$. Protein levels were determined using the Bradford method, and then the samples were mixed with
Laemmli buffer and denatured at $95{ }^{\circ} \mathrm{C}$ for 5 min. Equal amounts of proteins were separated on Native-PAGE gels (ASN preparations) or SDS/PAGE gels (cell lysates or immunoprecipitates). All proteins were transferred to nitrocellulose membranes at $100 \mathrm{~V}$. Membranes were washed for $5 \mathrm{~min}$ in TBS-Tween buffer (0.1\% TBST) (100 mM Tris-buffered saline, $140 \mathrm{mM} \mathrm{NaCl}$, and $0.1 \%$ Tween 20, $\mathrm{pH}$ 7.6) and the nonspecific bindings were blocked for $1 \mathrm{~h}$ at RT with $5 \%$ BSA in $0.1 \%$ TBST or with $5 \%$ non-fat milk solution in $0.1 \%$ TBST. Immunodetection was performed overnight at $4{ }^{\circ} \mathrm{C}$ using mouse anti-parkin (1:1000; Santa Cruz), rabbit anti-parkin (1:500; Cell Signaling), rabbit anti-alpha-synuclein (1:500; Sigma-Aldrich), rabbit anti-S-nitrosocysteine (1:1000; Sigma-Aldrich), or rabbit anti-ubiquitin (1:1000; Millipore) antibodies. Then, the membranes were washed three times (5 $\mathrm{min}$ ) in TBST and incubated for $60 \mathrm{~min}$ at RT with secondary antibody (anti-rabbit or anti-mouse $\operatorname{IgG})(1: 4000)$ in a $5 \%$ non-fat milk/TBST. Antibodies were detected using chemiluminescent Clarity Western ECL Substrate (Bio-Rad Laboratories, Hercules, CA, USA) under standard conditions. Immunolabeling of GAPDH (rabbit anti-GAPDH; 1:40,000; Sigma-Aldrich) for cell lysates or immunolabeling of rabbit anti-parkin for immunoprecipitates was performed as a loading control.

\section{Parkin In Vitro Autoubiquitination Assay}

Autoubiquitination of parkin was analyzed according to Yao et al. [10] with modifications. Briefly, parkin was immunoprecipitated with murine anti-parkin antibody, as described above. Immunoprecipitate was incubated in the presence of ubiquitin $(0.02 \mathrm{mg} / \mathrm{ml})$, ubiquitin-activating enzyme Ube1 ( $5 \mathrm{nM}$ ), and ubiquitin-conjugating enzyme UbcH4 $(100 \mathrm{nM})$ in ubiquitination buffer $(2 \mathrm{mM}$ ATP, $50 \mathrm{mM}$ Tris, $5 \mathrm{mM} \mathrm{MgCl}{ }_{2}$ at $\mathrm{pH} 8$ ) for $30 \mathrm{~min}$ at $37{ }^{\circ} \mathrm{C}$. Reaction was stopped by addition of $50 \mu \mathrm{l}$ of $2 \times$ concentrated Laemmli sample buffer and denaturation was performed for $5 \mathrm{~min}$ at $95^{\circ} \mathrm{C}$. After separation of beads on magnetic stand, samples were analyzed by SDS-PAGE and Western blotting with rabbit anti-ubiquitin antibody and rabbit anti-parkin antibody. Anti-ubiquitin immunoreactivity was normalized to antiparkin immunoreactivity.

\section{Cell Viability and Apoptosis}

Cellular viability was evaluated by the reduction of MTT to formazan. Low-serum medium containing investigated substances were added to the cells for $48 \mathrm{~h}$. MTT $(2.5 \mathrm{mg} / \mathrm{ml})$ was added to all wells and allowed to incubate at $37^{\circ} \mathrm{C}$ for $2 \mathrm{~h}$, followed by cell lysis and spectrophotometric measurement at $595 \mathrm{~nm}$.

The presence of apoptotic cells was determined by microscopic analysis of the cells stained with 2'-(4-hydroxyphenyl)- 
5-(4-methyl-1-piperazinyl)-2,5'-bi-1H-benzimidazole trihydrochloride hydrate, bisBenzimide (Hoechst 33258). Cells with typical apoptotic nuclear morphology (nuclear shrinkage, condensation) were identified and counted. The results were expressed as percentages of apoptotic bodies.

\section{Statistical Analysis}

The results were expressed as mean values \pm SEM. Differences between the means were analyzed using a Student's $t$ test between two groups and one-way or twoway analysis of variance ANOVA with Bonferroni comparison post hoc test among multiple groups. Statistical significance was accepted at $p<0.05$. The statistical analyses were performed using GraphPad Prism version 5.0 (GraphPad Software, San Diego, CA).

\section{Results}

Since oligomers and protofibrils, rather than mature fibrils of ASN, were previously shown to be the most pathogenic species involved in neurodegeneration [25, 31, 32], we generated ASN oligomeric species and confirmed their conformation state by measuring Thioflavin- $\mathrm{T}$ (ThT) fluorescence response upon binding to appropriate variants. We found that the ThT fluorescence is four and seven times more intense with ASN oligomers and protofibrils, respectively, compared to monomers (Fig. 1a). For morphological characterization of obtained preparations, TEM and AFM analyses were performed according to Danzer et al. [27]. We observed that ASN oligomers formed annular structures $40-45 \mathrm{~nm}$ in diameter. Importantly, these annular structures were not found in monomer preparations. ASN monomers showed an amorphous ultrastructure and, and as expected, ASN fibrils showed a fibrillar helical ultrastructure (Fig. 1b). Native-page electrophoresis and Western blot analysis revealed that ASN oligomers had assembled into supramolecular structures, much larger than monomers (Fig. 1c).

We first investigated whether those in vitro generated oligomeric species are able to activate the molecular mechanisms responsible for neuronal cells death. As an experimental model, we chose rat pheochromocytoma (PC12) cell line, because these cells are able to express a number of features characteristic for catecholaminergic neurons including tyrosine hydroxylase and dopamine- $\beta$-hydroxylase activities and were used in previous studies on mechanisms of ASN-induced cytotoxicity $[6,33,34]$.

In the present study, we exposed PC12 cells to generated oligomers to study their influence on cellular calcium homeostasis and oxidative stress. We observed that treatment of PC12 cells with ASN oligomers $(5 \mu \mathrm{M})$ resulted in significant $\left[\mathrm{Ca}^{2+}\right]_{\mathrm{i}}$ mobilization (Fig. 2a, b). Since calcium deregulation plays an important role in overactivation of nitric oxide synthase (NOS) that catalyzes the conversion of arginine into citrulline and NO, we next examined the level of the corresponding amino acids as well as intracellular NO levels. Our results showed that arginine was significantly decreased in PC12 cells treated with extracellular ASN together with the moderate increase in citrulline levels (Fig. 3a, b). Since arginine levels are also regulated by the activity of arginase, we also measured the level of the arginase product ornithine and observed that this was also significantly increased after ASN treatment (Fig. 3c). In the following experiments, we measured NO levels using the fluorescence dye DAF-2 DA. To determine the contribution of ASN oligomers on nitrosative stress, we used NAC, an antioxidant that also holds a high NO scavenging potency. As shown in cell-free system, NAC $(100 \mu \mathrm{M})$ decreased DAF-2 fluorescence intensity induced by NO donors, SNP $(500 \mu \mathrm{M})$ or Deano $(500 \mu \mathrm{M})$ (Fig. 3d). In PC12 cells, we found that ASN oligomers evoked a significant elevation in $\mathrm{NO}$ synthesis after $8 \mathrm{~h}$ of incubation (Fig. 3e). The progressive rise of the NO level in ASN-treated cells was observed even up to $24 \mathrm{~h}$ (Fig. 3f). Subsequently, pre-treatment of PC12 cells with NAC $(100 \mu \mathrm{M})$ or unselective NOS inhibitor, NNLA $(100 \mu \mathrm{M})$, significantly prevented the increase of NO level induced by ASN (Fig. 3e, f).

Our previous findings indicated that ASN-induced mitochondrial dysfunction was responsible for elevated oxidative stress [6]. In agreement with these earlier findings, cytosolic ROS level assayed by the DCF method was significantly elevated in PC12 cells treated with extracellular ASN for 8 and $24 \mathrm{~h}$ as compared to control PC12 cells (Fig. 4a). Simultaneously, we observed that ASN oligomers increase the expression of genes encoding stress-activated antioxidative enzymes localized in mitochondria: superoxide dismutase (Sod2), peroxiredoxin 3 ( $\operatorname{Prd} x 3$ ), topoizomerase 1 (Top $1 m t)$; or in cytosol: glutathione peroxidase $1(G p x l)$ and thioredoxin reductase 1 (Txnrd1). An increased expression of Gadd $45 \beta$ as a marker of cellular stress and DNA-damage was also observed in ASN-treated PC12 cells (Fig. 4b). To verify that the cytosolic redox environment was affected by the increase in ROS, PC12 cells were transiently transfected with a reporter gene coding for a roGFP (Fig. 4c) and treated with ASN oligomers for $24 \mathrm{~h}$. The results indicated that ASN significantly deregulates cellular redox state in PC12 cells. Moreover, this effect by ASN was significantly ameliorated by NAC pretreatment (Fig. 4d).

Because nitrosative and oxidative stress may affect parkin function, we investigated the effect of ASN treatment on parkin expression, $S$-nitrosylation, as well as its activity. Although ASN did not alter parkin mRNA levels (Fig. 5a), it significantly lowered parkin immunoreactivity (Fig. 5b). This effect of ASN on parkin protein levels was prevented by both NAC and NNLA (Fig. 5b). Western blot analysis of cysteine nitrosylation in immunoprecipitated parkin revealed 
A

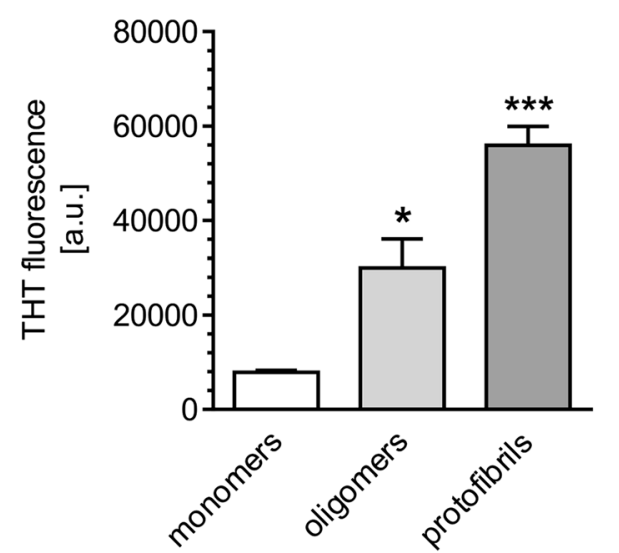

C

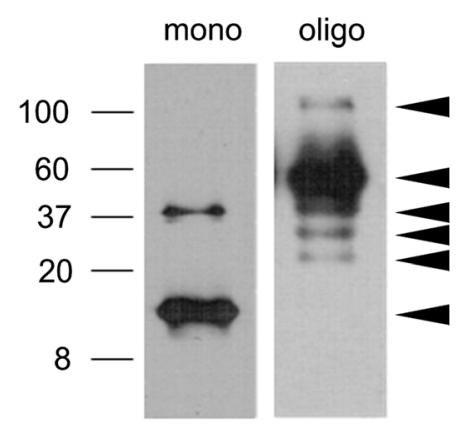

B

TEM monomers

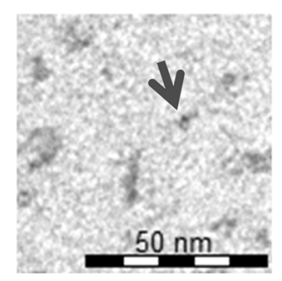

oligomers

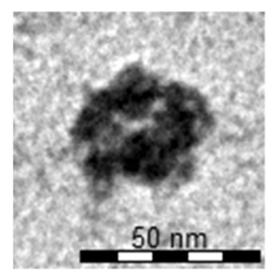

protofibrils

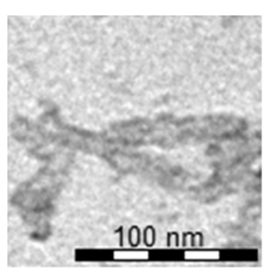

\section{AFM}

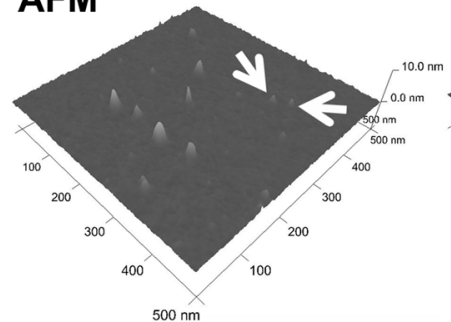

$500 \mathrm{~nm}$
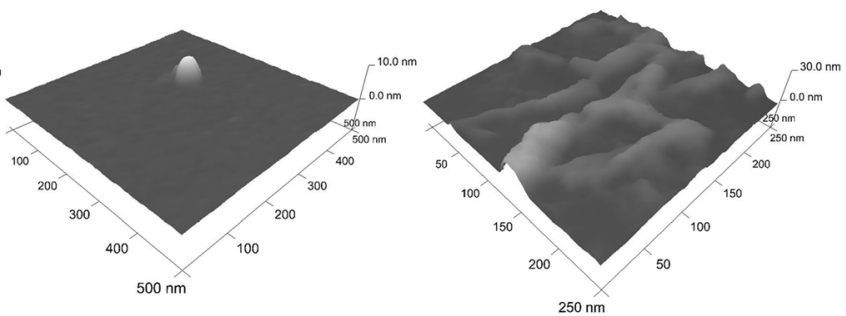

blotting with anti-ASN antibody of the ASN monomeric (mono) and oligomeric (oligo) forms were performed. The molecular masses of the particular bands (delineated by arrowheads) corresponding to monomeric and oligomeric states of ASN were computed using Total Lab software. Non-aggregated ASN mostly remains in the monomeric form (molecular mass $11 \mathrm{kDa}$ ), but to a small extent, it forms dimers and trimers with a molecular mass of $37 \mathrm{kDa}$. In the oligomeric preparations of ASN, no immunoreactive bands corresponding to monomeric forms was detected; however, the bands with apparent higher molecular masses of 25, 33, and 37 (characteristic for dimers and trimers), as well as 51 and $106 \mathrm{kDa}$ (larger oligomers) were resolved

We next determined whether ASN treatment modulated the ubiquitin E3 ligase activity of parkin. Parkin ubiquitinates itself; therefore, detection of ubiquitinated parkin serves as a reliable indicator of parkin's ubiquitin E3 ligase activity [35-37]. We found that autoubiquitination of parkin significantly increases after $24-\mathrm{h}$ treatment with ASN oligomers that $S$-nitrosylation of parkin in PC12 cells increases within $24 \mathrm{~h}$ of ASN oligomer exposure (Fig. 5c), whereas $48 \mathrm{~h}$ after ASN treatment, the level of $S$-nitrosylated parkin returned to basal levels (Fig. 5d). Similar to findings in previous experiments, 24-h treatment with NAC and NNLA prevented ASNevoked parkin $S$-nitrosylation (Fig. 5c). 

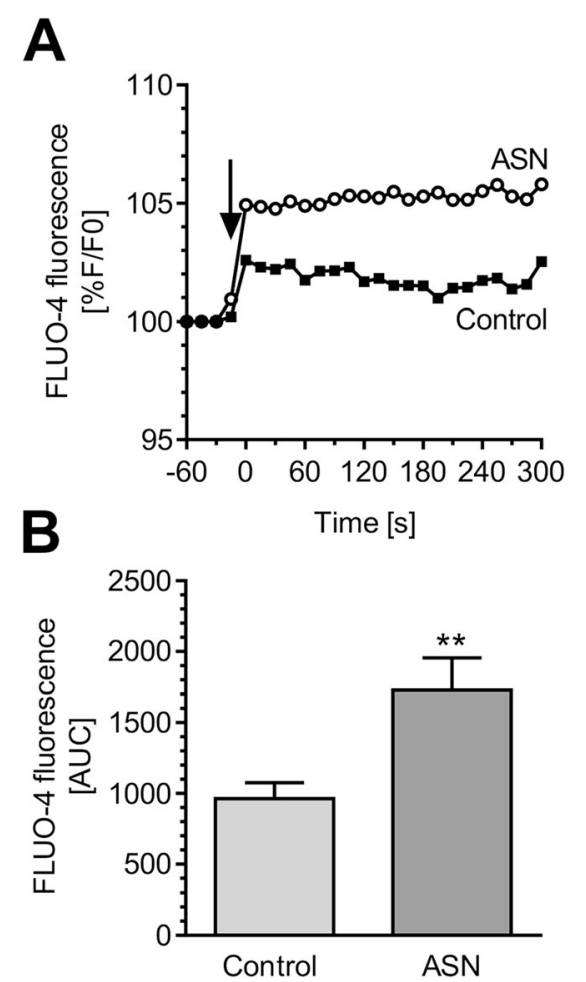

Fig. 2 The effect of ASN oligomers on calcium homeostasis in PC12 cells. a Cytoplasmatic calcium level in PC12 cells after 6 min treatment with $5 \mu \mathrm{M}$ ASN oligomers measured by FLUO-4 fluorescence. Arrow indicates compound administration. Data represent the mean value \pm SEM for three independent experiments. b Responses of FLUO-4 were quantitated by measuring the area under the curve (AUC) value. Data represent the mean value \pm SEM for three independent experiments. $* * p<0.01$ compared to control using Student's $t$ test

(Fig. 6a) and returns to the basal level at $48 \mathrm{~h}$ (Fig. 6b). Pretreatment with NAC or NNLA significantly prevented ASNinduced elevation in parkin autoubiquitination (Fig. 6a). To further confirm the effect of ASN on parkin's E3 ligase activity, we reconstituted the autoubiquitination reaction of parkin in vitro. Again, we observed that ASN markedly elevated the activity of parkin (Fig. 6c). Since parkin has many putative substrates, we monitored whether the ASN-induced changes in parkin activity affected the parkin-mediated protein ubiquitination. Although exogenous ASN-induced significant increases in parkin activity, we did not observe any substantial changes in the level of ubiquitinated proteins in $\mathrm{PC} 12$ cells treated with exogenous ASN for 24 h (Fig. 6d) or $48 \mathrm{~h}$ (Fig. 6e).

ASN-evoked calcium deregulation followed by oxidativenitrosative stress may significantly affect dopaminergic cells viability. We observed that pre-treatment with antioxidant or NOS inhibitor prevents toxicity evoked by ASN oligomers (Fig. 7a). Additionally, morphological examination of cell nuclei, stained with DNA-binding fluorochrome Hoechst 33342, showed that cells exposed to ASN oligomers presented typical apoptotic morphology, including condensation of chromatin and nuclear fragmentation (Fig. 7b, c). NOS inhibition as well as antioxidant pre-treatment prevented apoptotic cell death caused by extracellular ASN (Fig. 7b, c). To determine whether parkin deregulation is involved in cell death induced by exogenous ASN oligomers, we silenced endogenous parkin with siRNA (Supplementary Fig. S1). The $80 \%$ decrease in parkin expression in $\mathrm{PC} 12$ cells significantly reduced their viability, but this effect was less profound when compared to control PC12 cells treated with ASN (Fig. 8a). Notably, parkin silencing enhanced the toxicity of exogenous ASN (Fig. 8a). To determine the cytoprotective role of parkin against ASNinduced cell death, PC12 cells were transfected with human parkin gene, which resulted in sixfold increase in parkin protein levels when compared to control cells transfected with the empty vector (Supplementary Fig. S2). We observed that parkin overexpression significantly alleviated ASN-induced cell death when compared with empty vector-transfected cells, suggesting an important role of parkin against ASN-induced neurotoxicity (Fig. 8b).

\section{Discussion}

Although both ASN and parkin mutations and associated dysfunctions are linked to the molecular pathogenesis of PD, few studies investigated the functional interaction between those two proteins. In particular, the potential role of extracellular ASN oligomers on the deregulation of parkin in PD pathology has not been reported. In the present study, we show for the first time that nitrosative stress induced by exogenous ASN oligomers promotes parkin deregulation via $S$-nitrosylation followed by its degradation. Moreover, we demonstrate that parkin deregulation induced by ASN is partially responsible for the toxic effect of ASN in dopaminergic neural cells. Previous studies showed that various oxidative or nitrosative stress conditions can cause posttranslational modifications on parkin (sulfonation and $S$-nitrosylation, respectively) $[10,38]$. Moreover, various PD-related toxins were shown to induce alterations in parkin solubility, activity, and intracellular aggregation, resulting in increasing cell death, both in cell culture and in vivo $[12,38,39]$. It was also found that in the presence of various stressors, parkin accumulation into the insoluble fraction of neurons was promoted by endogenous ASN [39]. Our findings are thus consistent with previous studies in demonstrating the functional link between ASN and parkin $S$-nitrosylation in neuronal cells and extend earlier findings by showing that extracellular ASN may be a direct cause for parkin posttranslational modifications in neuronal cells.

Many studies indicated deregulation in calcium homeostasis and elevated release of nitric oxide as important mediators of toxicity induced by extracellular ASN [25]. Recently, it was demonstrated that the negative impact of aberrantly secreted ASN does not appear to involve internalization of this protein 

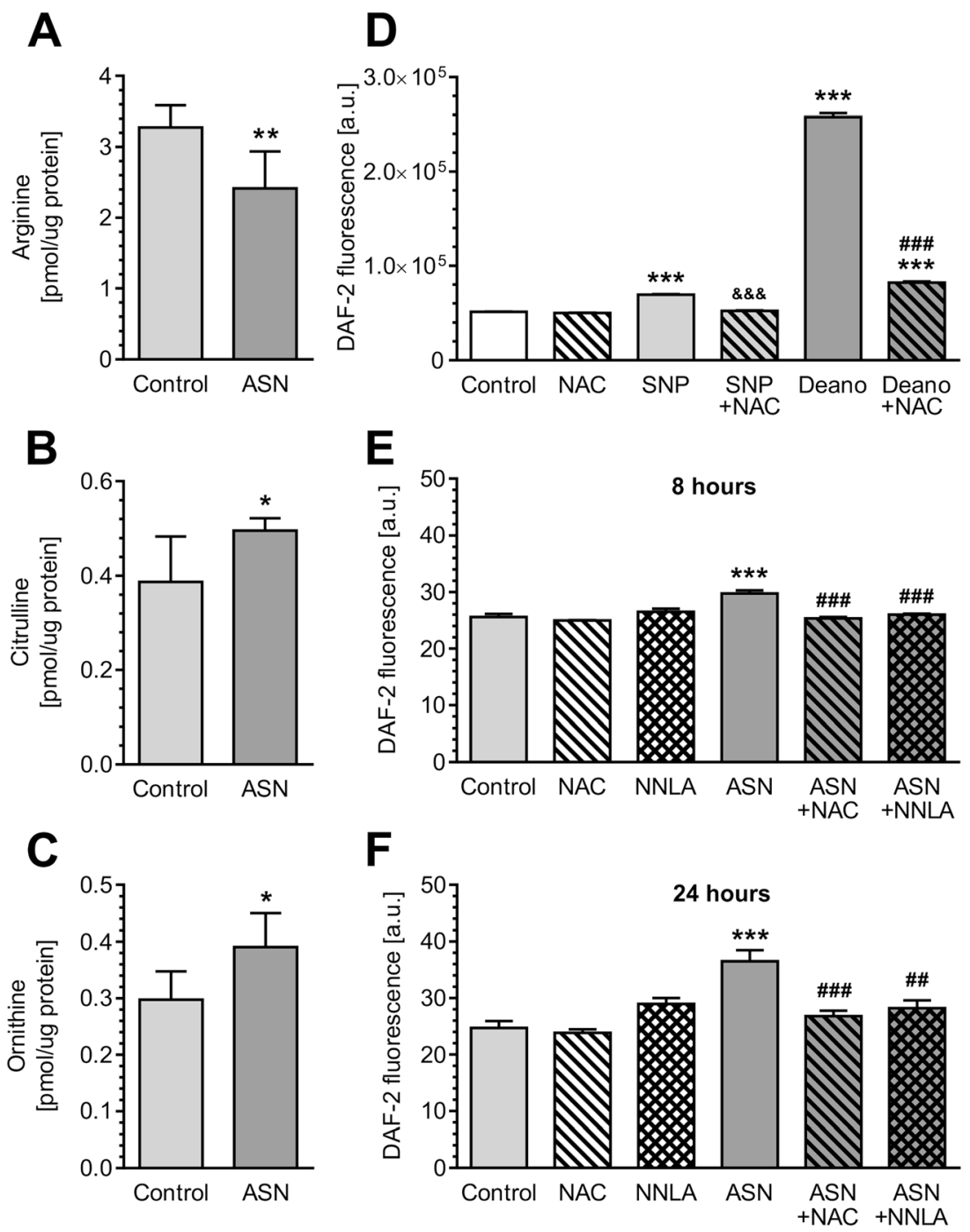

Fig. 3 ASN oligomers increase nitric oxide generation in PC12 cells. a Arginine levels in PC12 cells after 24-h incubation with $5 \mu \mathrm{M}$ ASN oligomers, as measured by HPLC method. Data represent the mean value \pm SEM of five independent experiments. $* * p<0.01$ compared to control, using Student's $t$ test. b Citrulline level in PC12 cells after 24-h incubation with $5 \mu \mathrm{M}$ ASN oligomers measured by HPLC method. Data represent the mean value \pm SEM of five independent experiments. $* p<0.05$ compared to control, Student's $t$ test. c Ornithine levels in PC12 cells after 24-h incubation with $5 \mu \mathrm{M}$ ASN oligomers measured by HPLC method. Data represent the mean value \pm SEM of five independent experiments. ${ }^{*} p<0.05$ compared to control, Student's $t$ test. d NO levels after 2-h incubation with $1 \mathrm{mM} N$-acetylcysteine (NAC), $500 \mu \mathrm{M}$ sodium nitroprusside (SNP), and $500 \mu \mathrm{M}$ Deano measured by DAF-2 fluorescence. Data represent the mean value \pm SEM for four independent experiments. ${ }^{* *} p<0.001$ compared to control, ${ }^{\& \& \&} \mathrm{p}<$ 0.001 compared to SNP, \#\#\#p<0.001 compared to Deano, using oneway ANOVA followed by Bonferroni post hoc test. e Intracellular NO level in PC12 cells after 8-h incubation with $5 \mu \mathrm{M}$ ASN oligomers in the presence of $1 \mathrm{mM}$ NAC or $100 \mu \mathrm{M}$ NNLA measured by DAF-2 fluorescence. Data represent the mean value \pm SEM for six independent experiments. $* * * p<0.001$ compared to control; \#\#\# $<0.001$ compared to ASN, using one-way ANOVA followed by Bonferroni post hoc test. $\mathbf{f}$ Intracellular NO level in PC12 cells after 24-h incubation with $5 \mu \mathrm{M}$ ASN oligomers in the presence of $1 \mathrm{mM}$ NAC or $100 \mu \mathrm{M}$ NNLA measured by DAF-2 fluorescence. Data represent the mean value \pm SEM for six independent experiments. $* * * p<0.001$ compared to control; $\# \# \#<<0.001 ; \# \# p<0.01$ compared to ASN, using one-way ANOVA followed by Bonferroni post-hoc test by the recipient neurons [40, 41], but it depends on deregulation of various plasma membrane receptors most of which are $\mathrm{Ca}^{2+}$ channels [28, 42, 43]. Alternatively, aberrant oligomeric structures of ASN were shown to evoke permeabilization of cellular membranes leading to uncontrolled $\mathrm{Ca}^{2+}$ influx and synaptic vesicular depletion [27, 44-47]. In our studies, we generated an oligomeric species of ASN that are able to form annular pore-like structures and observed that treatment of PC12 cells with those oligomers leads to significant increase in cellular $\mathrm{Ca}^{2+}$ concentration. Previous studies indicated that elevated calcium is responsible for ASN-induced activation of neuronal nitric oxide synthase (nNOS) and increased NO level [42]. In accordance with those data, our results showed that treatment with exogenous ASN results in elevated NO as well 
A
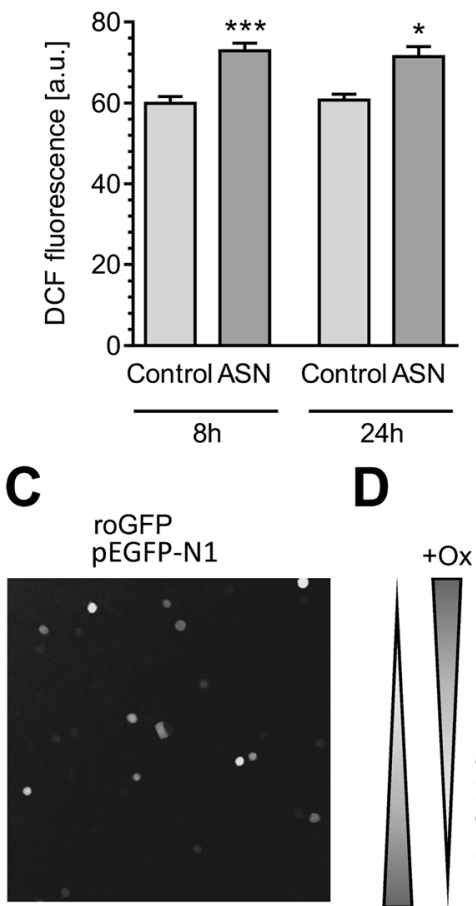

D

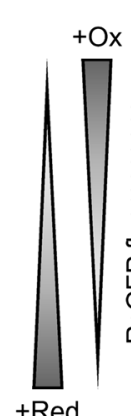

+ Red

Fig. 4 The effect of ASN oligomers on oxidative stress generation in PC12 cells. a Intracellular free radicals level in PC12 cells after 8- and 24-h incubation with $5 \mu \mathrm{M}$ ASN oligomers measured by DCF fluorescence. Data represent the mean value $\pm S E M$ for four independent experiments. $* * * p<0.001 ; * p<0.05$ compared to control, using Student's $t$ test. b Expression of stress response genes: Sod2, Prdx3, Top1mt, Gpx1, Txnrd1, and Gadd45b in PC12 cells after 24-h treatment with $5 \mu \mathrm{M}$ ASN oligomers measured by qRT-PCR. Data represent the mean value $\pm \mathrm{SEM}$ for four independent experiments. $* * p<0.01$;

as other free radical production. Under specific conditions, such as a low level of arginine or co-factors, NOS could additionally produce superoxide $\left(\mathrm{O}_{2}{ }^{-}\right)$or hydrogen peroxide $\left(\mathrm{H}_{2}\right.$ $\mathrm{O}_{2}$ ). Since in our study exogenous ASN induces significant decrease in arginine level, probably due to both NOS and arginase activation, this may create the favorable circumstances for free radical production and constitute one of the mechanisms of ASN-induced oxidative stress in neurons. Previous data showed that exogenous ASN is able to increase free radical levels by reducing mitochondrial complex I activity [48-50]. Alternatively, direct release of $\mathrm{H}_{2} \mathrm{O}_{2}$ and, subsequently, its conversion into hydroxyl radicals also occur during formation of ASN oligomers [51-53]. The simultaneous production of $\mathrm{NO}$ and $\mathrm{O}_{2}{ }^{-}$in oxidative stress conditions may lead to the formation of peroxynitrite $\left(\mathrm{ONOO}^{-}\right)$, which is a highly reactive free radical that causes modification of the macromolecules [54]. Although we observed the increasing antioxidative enzymes' expression, probably as a compensatory mechanism to the enhancement
B
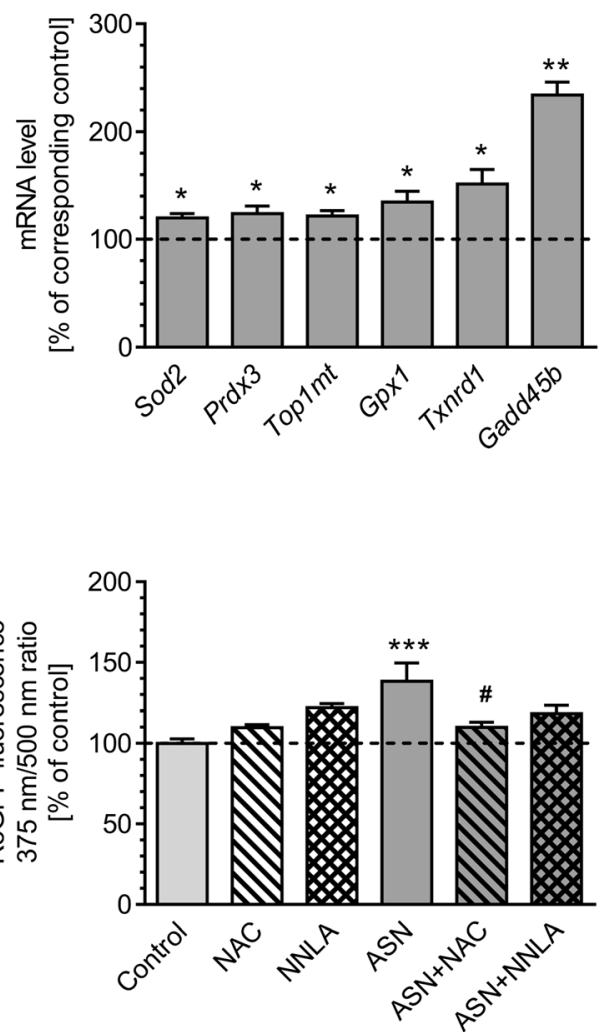

* $p<0.05$ compared to control, using a Student's $t$ test. c Representative confocal microscope image of PC12 cells transiently overexpressing roGFP protein. d Oxidative-reduction potential in PC12 cells after 8-h incubation with $5 \mu \mathrm{M}$ ASN oligomers in the presence of $1 \mathrm{mM} \mathrm{NAC}$ or $100 \mu \mathrm{M}$ NNLA measured by RoGFP fluorescence. Data represent the mean value \pm SEM for five independent experiments. $* * * p<0.001$ compared to control, \#p<0.05 compared to ASN, using one-way ANOVA followed by Bonferroni post hoc test

of ROS level, they are unable to readily detoxify the reactive intermediates and restore cellular redox homeostasis disrupted by ASN treatment. These results are with the agreement with previous data showing that accumulation of ASN in cells induces mitochondrial damage and disturbance in the balance between pro- and antioxidative mechanisms $[6,25,42,55]$.

Multiple lines of evidence indicate that oxidative and nitrosative stress could be one of the main causes of neuropathological changes observed in PD [Bhat et al., 2015; Wilkaniec et al., 2013; Dias et al., 2013]. Moreover, nitration or $S$-nitrosylation represents a probable mechanism contributing to the NO-induced misfolding of various proteins, including ASN (Gu et al. 2002; Cho et al. 2009; Nakamura and Lipton 2009). Previous in vitro reports indicated parkin $S$ nitrosylation after treatment with NO donors $[9,10]$, followed by observation of $S$-nitrosylated parkin in animal models of $\mathrm{PD}$, as well as in human brains with sporadic PD and diffuse Lewy body disease $[9,10,56]$. In line with those data, our 


\section{A}

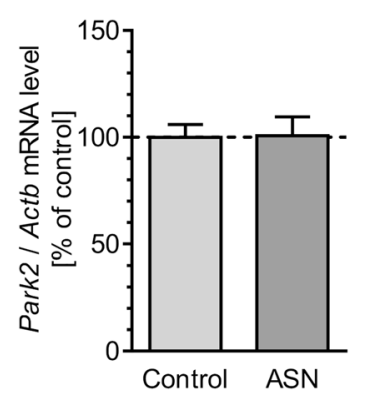

B

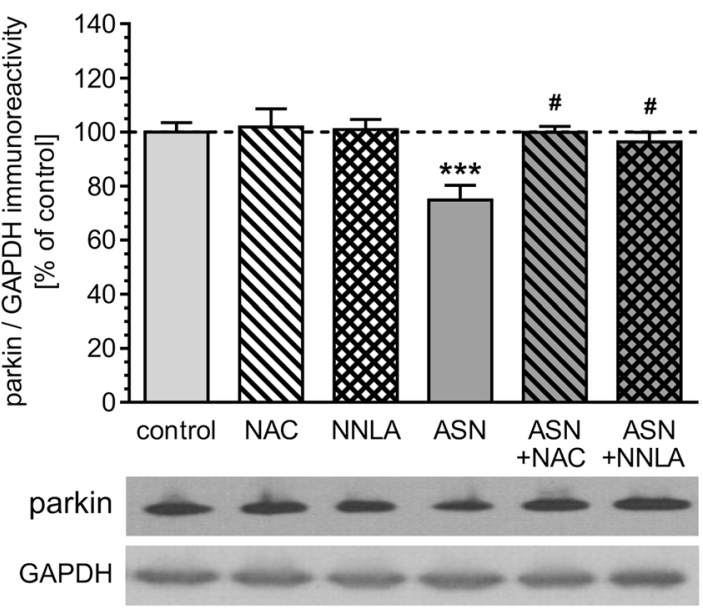

C

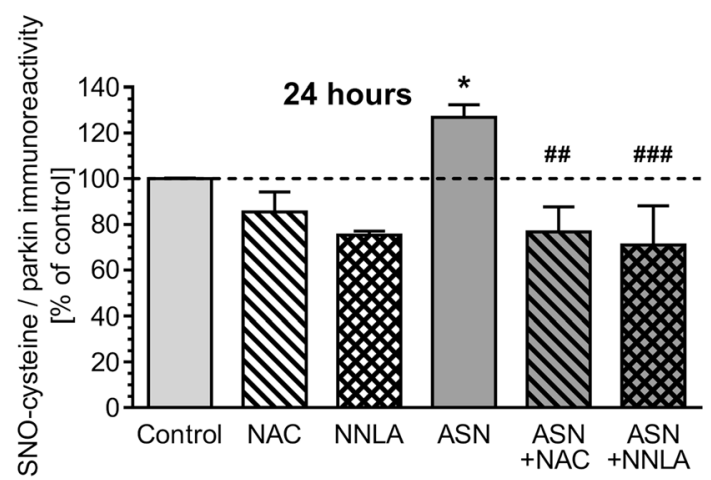

IP:parkin

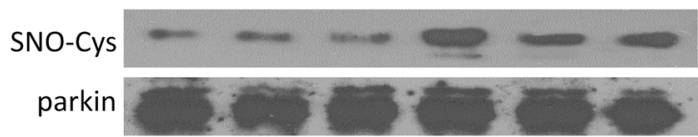

D

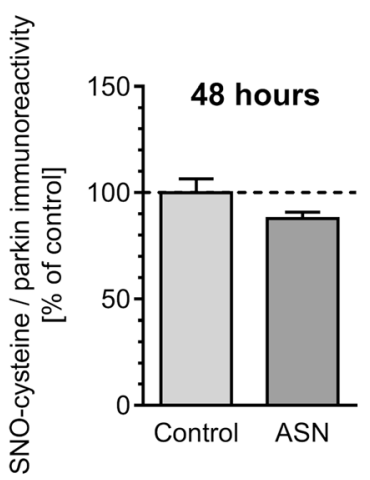

IP:parkin

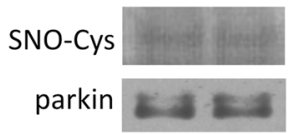

Fig. 5 The effect of ASN oligomers on parkin expression and $S$ nitrosylation in PC12 cells. a Expression of Park2 gene in PC12 cells after 24-h treatment with $5 \mu \mathrm{M}$ ASN oligomers measured by qRT-PCR. Results were normalized to actin $(A c t B)$ level. Data represent the mean value \pm SEM for four independent experiments ( $p=0.951$ by Student's $t$ test). b Parkin immunoreactivity in PC12 cells after 24-h treatment with $5 \mu \mathrm{M}$ ASN oligomers in the presence of $1 \mathrm{mM}$ NAC or $100 \mu \mathrm{M}$ NNLA measured by Western blot. Results were normalized to GAPDH level. Data represent the mean value \pm SEM for four independent experiments. $* * * p<0.001$ compared to control; \#p<0.05 compared to ASN, using one-way ANOVA followed by Bonferroni post hoc test. c Parkin $S$ nitrosylation in PC12 cells after 24 -h treatment with $5 \mu \mathrm{M}$ ASN

results showed that extracellular ASN, through activation of nitrosative stress, induces parkin $S$-nitrosylation and activation leading to decrease in parkin protein level. This is in agreement with previous study by Ozawa et al. [57], showing that endogenous $S$-nitrosylation of parkin is responsible for activation of its E3 ligase activity. Conversely, Dawson's group claimed that $S$-nitrosylation of parkin is responsible for its inhibition [9], whereas Yao et al. [10] showed that NO-mediated posttranslational modifications initially lead to oligomers in the presence of $1 \mathrm{mM}$ NAC or $100 \mu \mathrm{M}$ NNLA determined by ratio of $S$-nitrosocysteine (SNO-cysteine)/parkin immunoreactivity, measured by Western blot. Results were normalized to parkin level. Data represent the mean value \pm SEM for five independent experiments. ${ }^{*} p<0.05$ compared to control, \#\#p<0.01; $\# \# \# p<0.001$ compared to ASN, using one-way ANOVA followed by Bonferroni post hoc test. d Parkin $S$-nitrosylation in PC12 cells after 48-h treatment with $5 \mu \mathrm{M}$ ASN oligomers determined by the ratio of $S$ nitrosocysteine (SNO-cysteine)/parkin immunoreactivity, measured by Western blot. Results were normalized to parkin level. Data represent the mean value \pm SEM for five independent experiments $(p=0.107$ by Student's $t$ test)

a dramatic increase in parkin activity followed by a decrease in the E3 ligase-ubiquitin-proteasome degradative pathway. The possible reasons of discrepancies between results observed by these three groups were largely discussed in Ozawa's paper, suggesting that regulation of parkin ligase activity by $S$-nitrosylation/denitrosylation might be timedependent and that actually denitrosylation might be the cause of the reduced E3 ligase activity of parkin observed at later time points. 

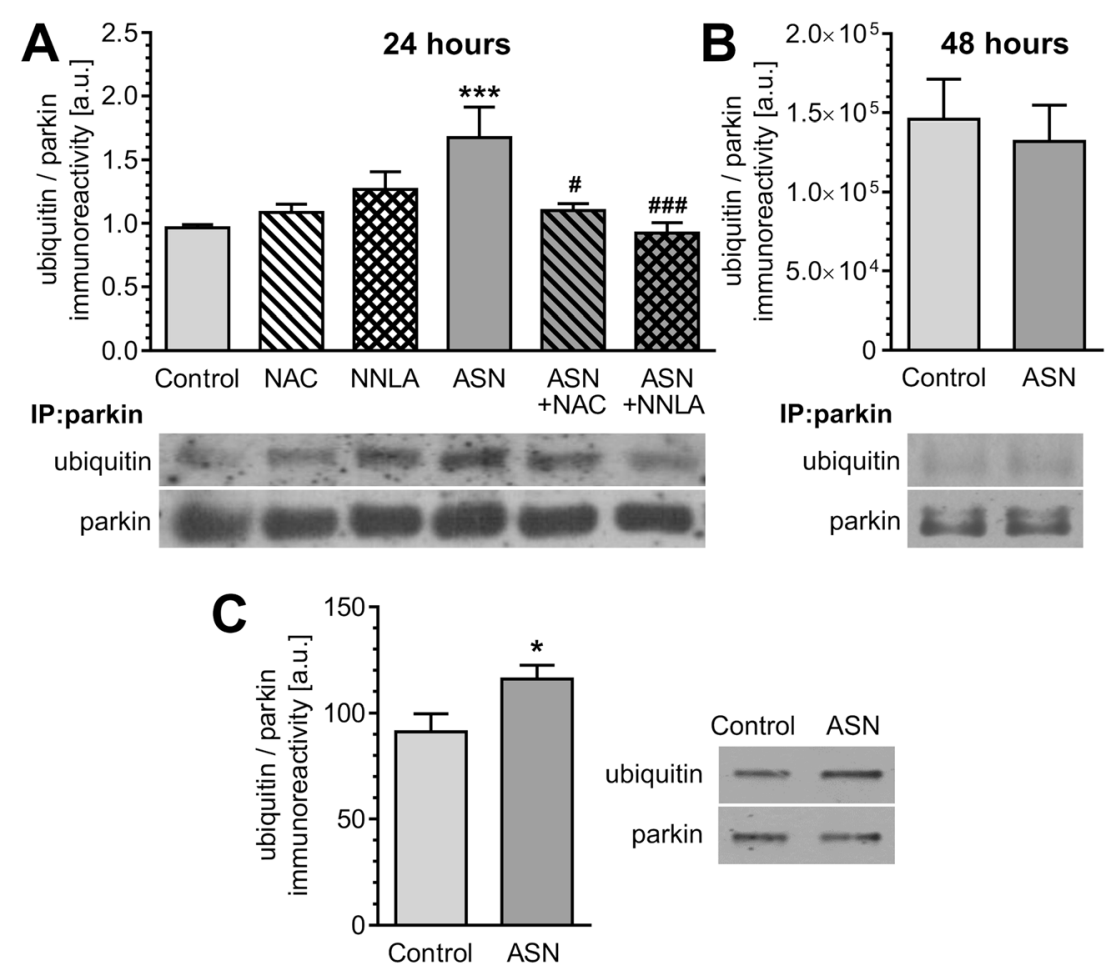

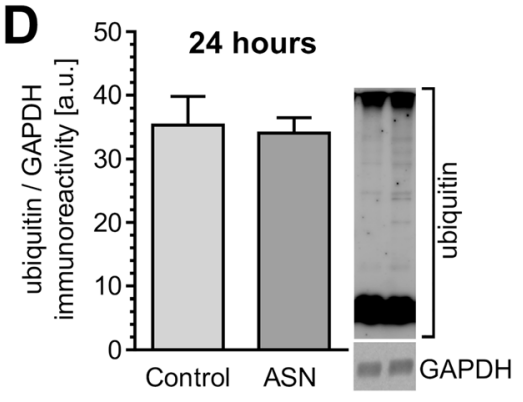

Fig. 6 The effect of ASN oligomers on protein ubiquitination and parkin activity in PC12 cells. a Parkin ubiquitination in PC12 cells after 24-h treatment with $5 \mu \mathrm{M}$ ASN oligomers in the presence of $1 \mathrm{mM} \mathrm{NAC}$ or $100 \mu \mathrm{M}$ NNLA measured by Western blot. Results were normalized to parkin level. Data represent the mean value \pm SEM for five independent

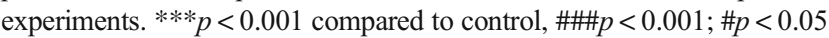
compared to ASN, using one-way ANOVA followed by Bonferroni post hoc test. b Parkin ubiquitination in PC12 cells after 48-h treatment with $5 \mu \mathrm{M}$ ASN measured by Western blot. Results were normalized to parkin level. Data represent the mean value \pm SEM for four independent experiments ( $p=0.703$ by Student's $t$ test). c Parkin activity in PC12 cells after 24 -h treatment with $5 \mu \mathrm{M}$ ASN determined by the ratio of

Interestingly, in our study, we observed that the level of $S$ nitrosylated parkin was greatly increased $24 \mathrm{~h}$ after ASN treatment and corresponded to the increase in parkin activity, while longer 48-h treatment normalized parkin activity to the basal level. These differences between our data and the results obtained by others might depend on the duration of NO release in cells. In previous papers, different NO donors or complex I inhibitors as well as the mitochondrial-uncoupling reagents induced fast increase, followed by significant decrease in

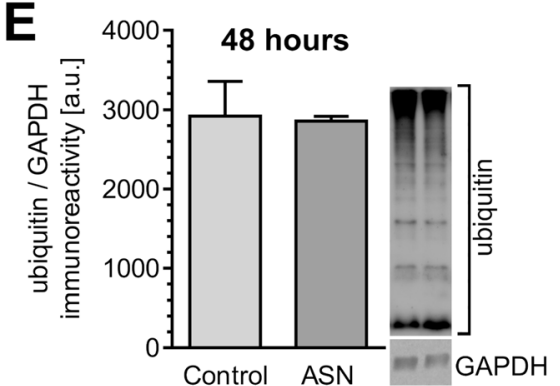

ubiquitin/parkin immunoreactivity measured by Western blot. Results were normalized to parkin level. Data represent the mean value \pm SEM for five independent experiments. $* p<0.05$ compared to control, using Student's $t$ test. d Protein ubiquitination in PC12 cells after 24-h treatment with $5 \mu \mathrm{M}$ ASN measured by Western blot. Results were normalized to GAPDH level. Data represent the mean value \pm SEM for five independent experiments ( $p=0.811$ by Student's $t$ test). e Protein ubiquitination in PC12 cells after 48-h treatment with $5 \mu \mathrm{M}$ ASN measured by Western blot. Results were normalized to GAPDH level. Data represent the mean value \pm SEM of four independent experiments ( $p=0.894$ by Student's $t$ test)

NO liberation [57]. This resulted in parkin $S$-nitrosylation up to $3 \mathrm{~h}$ of treatment followed by denitrosylation at time points when the NO level was no longer increased. In accordance with our previous data showing the progressive long-term rise of in the cytosolic $\mathrm{Ca}^{2+}$ in ASN-treated cells [33], we observed in this study that extracellular ASN induces long-lasting increase in NO level. Apart from deregulating NOS activity, extracellular ASN was demonstrated to exert its sustained action by elevation of nNOS expression [58]. Thus, we suggest 
A

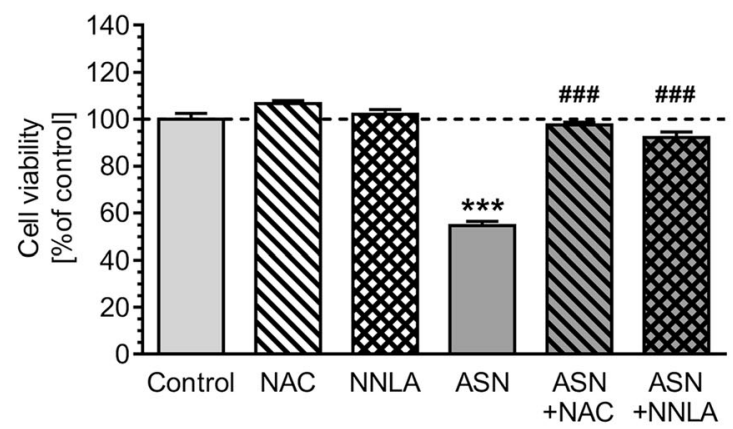

B

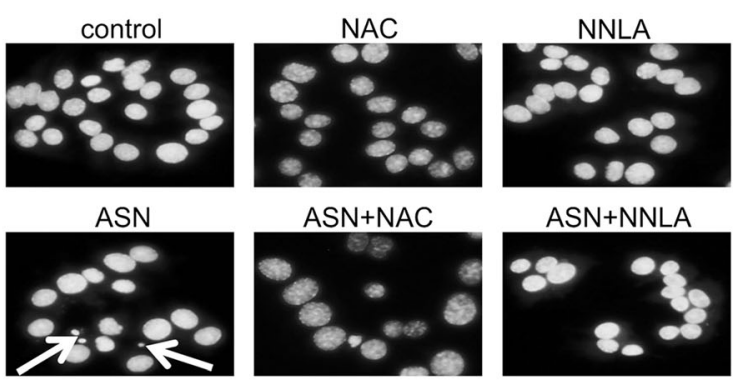

C

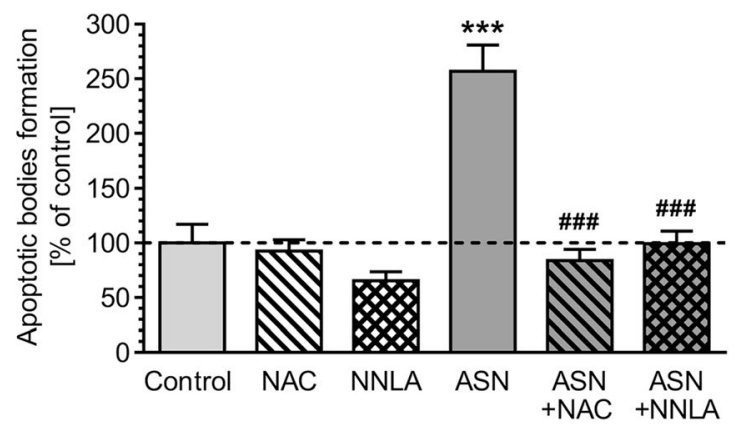

Fig. 7 The effect of ASN oligomers on PC12 cells viability. a PC12 cell viability after 48 -h treatment with $5 \mu \mathrm{M}$ ASN oligomers in the presence of $1 \mathrm{mM}$ NAC or $100 \mu \mathrm{M}$ NNLA measured by MTT test. Data represent the mean value \pm SEM for five independent experiments. $* * * p<0.001$ compared to control; \#\#\#p<0.001 compared to ASN, using one-way ANOVA followed by Bonferroni post hoc test. b Representative photomicrographs of apoptotic body formation in PC12 cells after 48-h treatment with $5 \mu \mathrm{M}$ ASN oligomers in the presence of $1 \mathrm{mM} \mathrm{NAC}$ or $100 \mu \mathrm{M}$ NNLA measured by Hoechst 33342 staining. The arrows indicate nuclei with typical apoptotic features. c Apoptotic body formation in PC12 cells after 48-h treatment with $5 \mu \mathrm{M}$ ASN oligomers in the presence of $1 \mathrm{mM}$ NAC or $100 \mu \mathrm{M}$ NNLA measured by Hoechst 33342 staining. Data represent the mean value \pm SEM for four independent experiments. $* * * p<0.001$ compared to control; $\# \# p<0.001$ compared to ASN, using one-way ANOVA followed by Bonferroni post hoc test

that the long-lasting elevation of NO level induced by extracellular ASN might result in prolonged parkin $S$-nitrosylation and activation. It is noteworthy that at the same time with the elevated autoubiquitination of parkin, the level of total ubiquitin did not change substantially after ASN treatment, suggesting that even though $S$-nitrosylation activates parkin, this enzyme is, at least in part, ineffective in marking its substrates for degradation. One possible explanation of this phenomenon
A
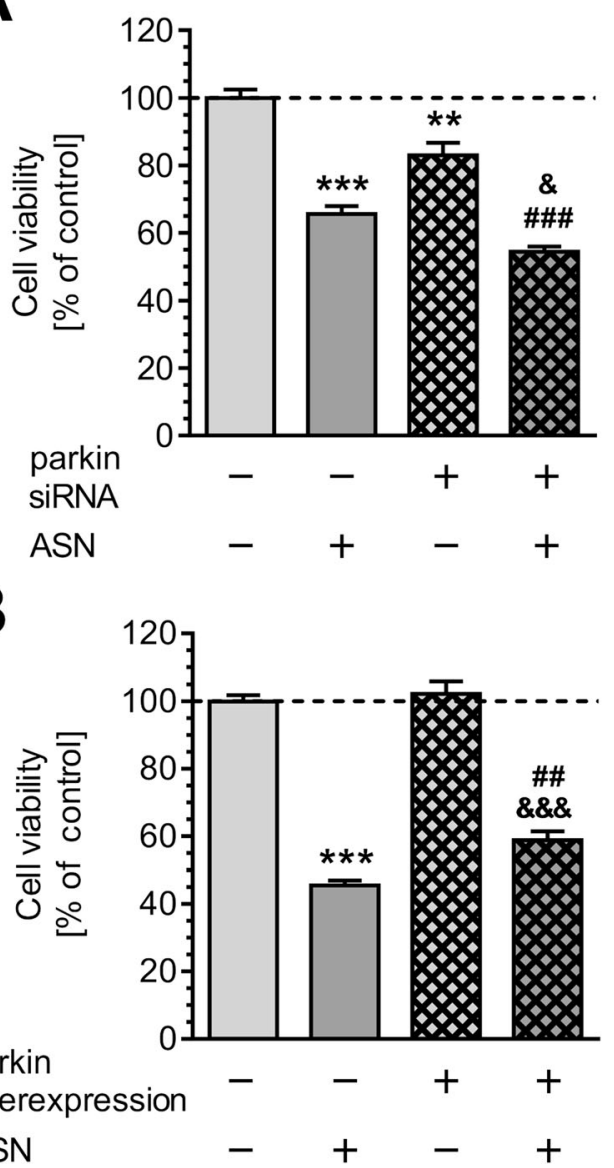

Fig. 8 The effect of ASN oligomers on parkin knock-down and parkin overexpression PC12 cell viability. a Parkin knock-down PC12 cells viability after 48 -h treatment with $5 \mu \mathrm{M}$ ASN oligomers measured by MTT test. Data represent the mean value \pm SEM for five independent experiments. $* * p<0.01 ; * * * p<0.001$ compared to control siRNA; \#\#p $<0.001$ compared parkin siRNA; ${ }^{\&} p<0.001$ compared to control siRNA + ASN, using two-way ANOVA followed by Bonferroni post hoc test. b Parkin overexpressed PC12 cell viability after 48-h treatment with $5 \mu \mathrm{M}$ ASN oligomers measured by MTT test. Data represent the mean value \pm SEM for five separate experiments. $* * * p<0.001$ compared to control; $\& \& \& p<0.001$ compared to parkin overexpressed cells; $\# \# p<0.01$ compared to control + ASN, using two-way ANOVA followed by Bonferroni post hoc test

is that while extracellular ASN increased the autoubiquitination of parkin through $S$-nitrosylation, at the same time, it decreased parkin protein levels, which resulted in dampening of the parkin E3 ubiquitin ligase activity. It was also concluded that autoubiquitination of parkin upon its $S$ nitrosylation may be directly responsible for inhibiting its E3 ligase activity, resulting in impaired ubiquitination and degradation of neurotoxic proteins, thereby contributing to their accumulation/aggregation resulting in ER stress and neuronal cell injury or death [59].

Finally, we found that either restoration of parkin homeostasis in PC12 cells by blocking its $S$-nitrosylation or elevation of parkin expression levels exerted cytoprotective effects 
against ASN oligomer toxicity. These findings are in agreement with currently emerging evidence indicating parkin as an important neuroprotective protein [60-62]. Previous reports demonstrated that E3 ubiquitin ligase activity of parkin was involved in many mechanisms regulating cell viability, such as, for example, governing mitochondrial quality control by triggering selective mitophagy [63] or participation in protein degradation during ER stress [64]. Thus, $S$-nitrosylation of parkin resulting in the inhibition of its ubiquitin E3 ligase activity may significantly contribute to the neurodegeneration by impairing these cytoprotective mechanisms [59].

Of note, the deleterious effects of ASN may not be completely dependent on deregulation of parkin, as silencing of parkin expression in PC12 cells induced already significant cell loss. This effect on cell viability, however, was less profound compared to the cytotoxicity evoked by ASN oligomers. It is in agreement with previous data showing that ASN is able to directly translocate to the mitochondria and disturb the Complex I function leading to neurodegeneration $[65,66]$. Moreover, the cellular accumulation of ASN was demonstrated to induce nitrosylation of many mitochondrial proteins [55], leading to dysfunction of these organelles followed by cytochrome $\mathrm{c}$ release, caspase- 3 activation, and p53-independent cell death $[6,67]$. Nevertheless, we observed that in the conditions when parkin is almost completely downregulated the toxic effects of ASN are significantly augmented, while parkin overexpression protects against ASN-evoked cell death. In agreement with these observations in the present study, it was demonstrated that parkin deficiency could be a trigger of oxidative stress and mitochondrial impairment [68] due to decreased cellular antioxidant defense, i.e., reduced glutathione levels and declining SOD activity [69]. On the other hand, parkin overexpression has been found to prevent neuronal degeneration induced by both mutant and wild-type ASN in primary neurons or neuroblastoma cells $[70,71]$. This suggests that parkin can protect neuronal cells against the ASN toxicity, but in the conditions of exacerbated oxidative/ nitrosative stress, this protective effect may be abrogated by $S$ nitrosylation of parkin leading to its degradation.

In summary, our data is the first to show that ASNdependent induction of oxidative/nitrosative stress is a key molecular process involved in parkin $S$-nitrosylation leading to dysregulation of its activity and degradation. Those new findings provide compelling evidence for direct association of parkin dysfunction to extracellular ASN-signaling as a critical phenomenon occurring in pathophysiology of sporadic PD. Thus, inhibiting parkin $S$-nitrosylation or elevating its level may contribute to the development of new therapies for $\mathrm{PD}$ and other synucleinopathies.

Acknowledgements Financial support was provided by the National Science Centre grants 2012/05/B/NZ3/02047 to A.A. and 2013/09/D/ NZ3/0135 to A.W. (studies of the redox potential). The sponsors of this study were not involved in the study design; in collection, analysis, and interpretation of data, in the writing of the report; or in the decision to submit the paper for publication. Authors would like to thank the Laboratory of Advanced Microscopy Techniques MMRC PAS for performing confocal microscope studies as well as Dr. Julita Nowakowska at the Laboratory of Electron and Confocal Microscopy, Faculty of Biology and Dr. Marcin Strawski at the Laboratory of Electrochemistry, Faculty of Chemistry, University of Warsaw for performing TEM and AFM analysis, respectively.

Open Access This article is distributed under the terms of the Creative Commons Attribution 4.0 International License (http:// creativecommons.org/licenses/by/4.0/), which permits unrestricted use, distribution, and reproduction in any medium, provided you give appropriate credit to the original author(s) and the source, provide a link to the Creative Commons license, and indicate if changes were made.

\section{References}

1. Baptista MJ, Cookson MR, Miller DW (2004) Parkin and alphasynuclein: opponent actions in the pathogenesis of Parkinson's disease. Neuroscientist 10:63-72. https://doi.org/10.1177/ 1073858403260392

2. Benskey MJ, Perez RG, Manfredsson FP (2016) The contribution of alpha synuclein to neuronal survival and function - implications for Parkinson's disease. J Neurochem 137:331-359. https://doi.org/ 10.1111/jnc. 13570

3. Bengoa-Vergniory N, Roberts RF, Wade-Martins R, AlegreAbarrategui J (2017) Alpha-synuclein oligomers: a new hope. Acta Neuropathol 134:819-838. https://doi.org/10.1007/s00401017-1755-1

4. Roberts HL, Brown DR (2015) Seeking a mechanism for the toxicity of oligomeric alpha-synuclein. Biomol Ther 5:282-305. https://doi.org/10.3390/biom5020282

5. Brown DR (2010) Oligomeric alpha-synuclein and its role in neuronal death. IUBMB Life 62:334-339. https://doi.org/10.1002/iub. 316

6. Kazmierczak A, Strosznajder JB, Adamczyk A (2008) alphaSynuclein enhances secretion and toxicity of amyloid beta peptides in PC12 cells. Neurochem Int 53:263-269. https://doi.org/10.1016/ j.neuint.2008.08.004

7. Xilouri M, Brekk OR, Stefanis L (2016) Autophagy and alphaSynuclein: relevance to Parkinson's disease and related synucleopathies. Mov Disord 31:178-192. https://doi.org/10. $1002 /$ mds. 26477

8. Mazzulli JR, Zunke F, Isacson O, Studer L, Krainc D (2016) alphaSynuclein-induced lysosomal dysfunction occurs through disruptions in protein trafficking in human midbrain synucleinopathy models. Proc Natl Acad Sci U S A 113:1931-1936. https://doi. org/10.1073/pnas.1520335113

9. Chung KKK, Thomas B, Li X, Pletnikova O, Troncoso JC, Marsh L, Dawson VL, Dawson TM (2004) S-nitrosylation of parkin regulates ubiquitination and compromises parkin's protective function. Science 304:1328-1331. https://doi.org/10.1126/science.1093891

10. Yao D, Gu Z, Nakamura T, Shi ZQ, Ma Y, Gaston B, Palmer LA, Rockenstein EM et al (2004) Nitrosative stress linked to sporadic Parkinson's disease: S-nitrosylation of parkin regulates its E3 ubiquitin ligase activity. Proc Natl Acad Sci U S A 101:10810-10814. https://doi.org/10.1073/pnas.0404161101

11. Wong ES, Tan JM, Wang C et al (2007) Relative sensitivity of parkin and other cysteine-containing enzymes to stress-induced solubility alterations. J Biol Chem 282:12310-12318. https://doi.org/ 10.1074/jbc.M609466200 
12. Wang C, Ko HS, Thomas B, Tsang F, Chew KCM, Tay SP, Ho MWL, Lim TM et al (2005) Stress-induced alterations in parkin solubility promote parkin aggregation and compromise parkin's protective function. Hum Mol Genet 14:3885-3897. https://doi. org $/ 10.1093 / \mathrm{hmg} / \mathrm{ddi} 413$

13. LaVoie MJ, Ostaszewski BL, Weihofen A, Schlossmacher MG, Selkoe DJ (2005) Dopamine covalently modifies and functionally inactivates parkin. Nat Med 11:1214-1221. https://doi.org/10. 1038/nm1314

14. Dawson TM, Dawson VL (2010) The role of parkin in familial and sporadic Parkinson's disease. Mov Disord 25:S32-S39. https://doi. org $/ 10.1002 / \mathrm{mds} .22798$

15. Bingol B, Sheng M (2016) Mechanisms of mitophagy: PINK1, Parkin, USP30 and beyond. Free Radic Biol Med 100:210-222. https://doi.org/10.1016/j.freeradbiomed.2016.04.015

16. Eiyama A, Okamoto K (2015) PINK1/Parkin-mediated mitophagy in mammalian cells. Curr Opin Cell Biol 33:95-101. https://doi.org/ 10.1016/j.ceb.2015.01.002

17. Wang X, Winter D, Ashrafi G, Schlehe J, Wong YL, Selkoe D, Rice S, Steen J et al (2011) PINK1 and Parkin target Miro for phosphorylation and degradation to arrest mitochondrial motility. Cell 147: 893-906. https://doi.org/10.1016/j.cell.2011.10.018

18. Shimura H, Schlossmacher MG, Hattori N, Frosch MP, Trockenbacher A, Schneider R, Mizuno Y, Kosik KS et al (2001) Ubiquitination of a new form of alpha-synuclein by parkin from human brain: implications for Parkinson's disease. Science 293: 263-269. https://doi.org/10.1126/science.1060627

19. Xilouri M, Brekk OR, Stefanis L (2013) alpha-Synuclein and protein degradation systems: a reciprocal relationship. Mol Neurobiol 47:537-551. https://doi.org/10.1007/s12035-012-8341-2

20. Ebrahimi-Fakhari D, Cantuti-Castelvetri I, Fan Z, Rockenstein E, Masliah E, Hyman BT, McLean PJ, Unni VK (2011) Distinct roles in vivo for the ubiquitin-proteasome system and the autophagylysosomal pathway in the degradation of $\alpha$-synuclein. J Neurosci 31:14508-14520. https://doi.org/10.1523/JNEUROSCI.1560-11. 2011

21. Tofaris GK, Layfield R, Spillantini MG (2001) Alpha-synuclein metabolism and aggregation is linked to ubiquitin-independent degradation by the proteasome. FEBS Lett 509:22-26

22. Mizuno Y, Hattori N, Mori H, Suzuki T, Tanaka K (2001) Parkin and Parkinson's disease. Curr Opin Neurol 14:477-482

23. Lonskaya I, Desforges NM, Hebron ML, Moussa CEH (2013) Ubiquitination increases parkin activity to promote autophagic $\alpha$ synuclein clearance. PLoS One 8:e83914. https://doi.org/10.1371/ journal.pone. 0083914

24. Khandelwal PJ, Dumanis SB, Feng LR, Maguire-Zeiss K, Rebeck G, Lashuel HA (2010) Parkinson-related parkin reduces alphaSynuclein phosphorylation in a gene transfer model. Mol Neurodegener 5:47. https://doi.org/10.1186/1750-1326-5-47

25. Wilkaniec A, Strosznajder JB, Adamczyk A (2013) Toxicity of extracellular secreted alpha-synuclein: its role in nitrosative stress and neurodegeneration. Neurochem Int 62:776-783. https://doi. org/10.1016/j.neuint.2013.02.004

26. Schlossmacher MG, Frosch MP, Gai WP, Medina M, Sharma N, Forno L, Ochiishi T, Shimura $\mathrm{H}$ et al (2002) Parkin localizes to the Lewy bodies of Parkinson disease and dementia with Lewy bodies. Am J Pathol 160:1655-1667. https://doi.org/10.1016/s00029440(10)61113-3

27. Danzer KM, Haasen D, Karow AR, Moussaud S, Habeck M, Giese A, Kretzschmar H, Hengerer B et al (2007) Different species of alpha-synuclein oligomers induce calcium influx and seeding. $\mathrm{J}$ Neurosci 27:9220-9232. https://doi.org/10.1523/jneurosci.261707.2007

28. Wilkaniec A, Gassowska M, Czapski GA, Cieslik M, Sulkowski G, Adamczyk A (2017) P2X7 receptor-pannexin 1 interaction mediates extracellular alpha-synuclein-induced ATP release in neuroblastoma SH-SY5Y cells. Purinergic Signal 13:347-361. https://doi.org/10.1007/s11302-017-9567-2

29. Jesko H, Wilkaniec A, Cieslik M, Hilgier W, Gassowska M, Lukiw WJ, Adamczyk A (2016) Altered arginine metabolism in cells transfected with human wild-type beta amyloid precursor protein (betaAPP). Curr Alzheimer Res 13:1030-1039

30. Cannon MB, Remington SJ (2006) Re-engineering redox-sensitive green fluorescent protein for improved response rate. Protein Sci 15:45-57. https://doi.org/10.1110/ps.051734306

31. Majbour NK, Vaikath NN, van Dijk KD, Ardah MT, Varghese S, Vesterager LB, Montezinho LP, Poole S et al (2016) Oligomeric and phosphorylated alpha-synuclein as potential CSF biomarkers for Parkinson's disease. Mol Neurodegener 11:7. https://doi.org/10. 1186/s13024-016-0072-9

32. Danzer KM, Kranich LR, Ruf WP, Cagsal-Getkin O, Winslow AR, Zhu L, Vanderburg CR, McLean PJ (2012) Exosomal cell-to-cell transmission of alpha synuclein oligomers. Mol Neurodegener 7: 42. https://doi.org/10.1186/1750-1326-7-42

33. Czapski GA, Gassowska M, Wilkaniec A, Cieslik M, Adamczyk A (2013) Extracellular alpha-synuclein induces calpain-dependent overactivation of cyclin-dependent kinase 5 in vitro. FEBS Lett 587:3135-3141. https://doi.org/10.1016/j.febslet.2013.07.053

34. Gassowska M, Czapski GA, Pajak B, Cieslik M, Lenkiewicz AM, Adamczyk A (2014) Extracellular alpha-synuclein leads to microtubule destabilization via GSK-3beta-dependent Tau phosphorylation in PC12 cells. PLoS One 9:e94259. https://doi.org/10.1371/ journal.pone.0094259

35. Imai Y, Soda M, Takahashi R (2000) Parkin suppresses unfolded protein stress-induced cell death through its E3 ubiquitin-protein ligase activity. J Biol Chem 275:35661-35664. https://doi.org/10. 1074/jbc.C000447200

36. Shimura H, Hattori N, Kubo S et al (2000) Familial Parkinson disease gene product, parkin, is a ubiquitin-protein ligase. Nat Genet 25:302-305. https://doi.org/10.1038/77060

37. Zhang Y, Gao J, Chung KK, Huang H, Dawson VL, Dawson TM (2000) Parkin functions as an E2-dependent ubiquitin- protein ligase and promotes the degradation of the synaptic vesicleassociated protein, CDCrel-1. Proc Natl Acad Sci U S A 97: 13354-13359. https://doi.org/10.1073/pnas.240347797

38. Meng F, Yao D, Shi Y, Kabakoff J, Wu W, Reicher J, Ma Y, Moosmann B et al (2011) Oxidation of the cysteine-rich regions of parkin perturbs its E3 ligase activity and contributes to protein aggregation. Mol Neurodegener 6:34. https://doi.org/10.1186/ 1750-1326-6-34

39. Kawahara K, Hashimoto M, Bar-On P, Ho GJ, Crews L, Mizuno H, Rockenstein E, Imam SZ et al (2008) $\alpha$-Synuclein aggregates interfere with Parkin solubility and distribution: role in the pathogenesis of Parkinson disease. J Biol Chem 283:6979-6987. https://doi. org/10.1074/jbc.M710418200

40. Emmanouilidou E, Melachroinou K, Roumeliotis T, Garbis SD, Ntzouni M, Margaritis LH, Stefanis L, Vekrellis K (2010) Cellproduced alpha-synuclein is secreted in a calcium-dependent manner by exosomes and impacts neuronal survival. J Neurosci 30: 6838-6851. https://doi.org/10.1523/jneurosci.5699-09.2010

41. Melachroinou K, Xilouri M, Emmanouilidou E, Masgrau R, Papazafiri P, Stefanis L, Vekrellis K (2013) Deregulation of calcium homeostasis mediates secreted $\alpha$-synuclein-induced neurotoxicity. Neurobiol Aging 34:2853-2865. https://doi.org/10.1016/j. neurobiolaging.2013.06.006

42. Adamczyk A, Czapski GA, Kazmierczak A, Strosznajder JB (2009) Effect of N-methyl-D-aspartate (NMDA) receptor antagonists on alpha-synuclein-evoked neuronal nitric oxide synthase activation in the rat brain. Pharmacol Rep 61:1078-1085

43. Adamczyk A, Strosznajder JB (2006) Alpha-synuclein potentiates $\mathrm{Ca} 2+$ influx through voltage-dependent $\mathrm{Ca} 2+$ channels. 
Neuroreport 17:1883-1886. https://doi.org/10.1097/WNR. 0b013e3280115185

44. Tsigelny IF, Sharikov Y, Wrasidlo W, Gonzalez T, Desplats PA, Crews L, Spencer B, Masliah E (2012) Role of $\alpha$-synuclein penetration into the membrane in the mechanisms of oligomer pore formation. FEBS J 279:1000-1013. https://doi.org/10.1111/j. 1742-4658.2012.08489.x

45. Stöckl MT, Zijlstra N, Subramaniam V (2013) $\alpha$-Synuclein oligomers: an amyloid pore? Mol Neurobiol 47:613-621. https://doi.org/ 10.1007/s12035-012-8331-4

46. van Rooijen BD, Claessens MM, Subramaniam V (2010) Membrane interactions of oligomeric alpha-synuclein: potential role in Parkinson's disease. Curr Protein Pept Sci 11:334-342

47. Pacheco CR, Morales CN, Ramirez AE, Munoz FJ, Gallegos SS, Caviedes PA, Aguayo LG, Opazo CM (2015) Extracellular alphasynuclein alters synaptic transmission in brain neurons by perforating the neuronal plasma membrane. J Neurochem 132:731-741. https://doi.org/10.1111/jnc. 13060

48. Devi L, Raghavendran V, Prabhu BM, Avadhani NG, Anandatheerthavarada HK (2008) Mitochondrial import and accumulation of alpha-synuclein impair complex I in human dopaminergic neuronal cultures and Parkinson disease brain. J Biol Chem 283:9089-9100. https://doi.org/10.1074/jbc.M710012200

49. Chinta SJ, Mallajosyula JK, Rane A, Andersen JK (2010) Mitochondrial alpha-synuclein accumulation impairs complex I function in dopaminergic neurons and results in increased mitophagy in vivo. Neurosci Lett 486:235-239. https://doi.org/ 10.1016/j.neulet.2010.09.061

50. Reeve AK, Ludtmann MH, Angelova PR, Simcox EM, Horrocks MH, Klenerman D, Gandhi S, Turnbull DM et al (2015) Aggregated alpha-synuclein and complex I deficiency: exploration of their relationship in differentiated neurons. Cell Death Dis 6: e1820. https://doi.org/10.1038/cddis.2015.166

51. Masliah E, Rockenstein E, Veinbergs I, Mallory M, Hashimoto M, Takeda A, Sagara Y, Sisk A et al (2000) Dopaminergic loss and inclusion body formation in alpha-synuclein mice: implications for neurodegenerative disorders. Science 287:1265-1269

52. Turnbull S, Tabner BJ, El-Agnaf OM, Moore S, Davies Y, Allsop D (2001) alpha-Synuclein implicated in Parkinson's disease catalyses the formation of hydrogen peroxide in vitro. Free Radic Biol Med 30:1163-1170

53. Deas E, Cremades N, Angelova PR, Ludtmann MHR, Yao Z, Chen S, Horrocks MH, Banushi B et al (2016) Alpha-Synuclein oligomers interact with metal ions to induce oxidative stress and neuronal death in Parkinson's disease. Antioxid Redox Signal 24:376391. https://doi.org/10.1089/ars.2015.6343

54. Radi R (2013) Peroxynitrite, a stealthy biological oxidant. J Biol Chem 288:26464-26472. https://doi.org/10.1074/jbc.R113.472936

55. Parihar MS, Parihar A, Fujita M, Hashimoto M, Ghafourifar P (2009) Alpha-synuclein overexpression and aggregation exacerbates impairment of mitochondrial functions by augmenting oxidative stress in human neuroblastoma cells. Int J Biochem Cell Biol 41:2015-2024. https://doi.org/10.1016/j.biocel.2009.05.008

56. Sunico CR, Nakamura T, Rockenstein E, Mante M, Adame A, Chan S, Newmeyer T, Masliah E et al (2013) S-Nitrosylation of parkin as a novel regulator of $\mathrm{p} 53$-mediated neuronal cell death in sporadic Parkinson's disease. Mol Neurodegener 8:29. https://doi. org/10.1186/1750-1326-8-29

57. Ozawa K, Komatsubara AT, Nishimura Y, Sawada T, Kawafune H, Tsumoto H, Tsuji Y, Zhao J et al (2013) S-nitrosylation regulates mitochondrial quality control via activation of parkin. Sci Rep 3: 2202. https://doi.org/10.1038/srep02202

58. Adamczyk A, Kazmierczak A, Czapski GA, Strosznajder JB (2010) Alpha-synuclein induced cell death in mouse hippocampal (HT22) cells is mediated by nitric oxide-dependent activation of caspase-3. FEBS Lett 584:3504-3508. https://doi.org/10.1016/j. febslet.2010.07.019

59. Nakamura T, Tu S, Akhtar Mohd W, Sunico Carmen R, Okamoto S-i, Lipton Stuart A (2013) Aberrant protein S-Nitrosylation in neurodegenerative diseases. Neuron 78:596-614. https://doi.org/ 10.1016/j.neuron.2013.05.005

60. Kramer ER (2015) The neuroprotective and regenerative potential of parkin and GDNF/Ret signaling in the midbrain dopaminergic system. Neural Regen Res 10:1752-1753. https://doi.org/10.4103/ 1673-5374.165295

61. Meka DP, Muller-Rischart AK, Nidadavolu P et al (2015) Parkin cooperates with GDNF/RET signaling to prevent dopaminergic neuron degeneration. J Clin Invest 125:1873-1885. https://doi. org/10.1172/jci79300

62. Tang J, Hu Z, Tan J, Yang S, Zeng L (2016) Parkin protects against oxygen-glucose deprivation/reperfusion insult by promoting Drp1 degradation. Oxidative Med Cell Longev 2016:8474303. https:// doi.org/10.1155/2016/8474303

63. Pickrell AM, Youle RJ (2015) The roles of PINK1, Parkin and mitochondrial fidelity in Parkinson's disease. Neuron 85:257-273. https://doi.org/10.1016/j.neuron.2014.12.007

64. Wang HQ, Takahashi R (2007) Expanding insights on the involvement of endoplasmic reticulum stress in Parkinson's disease. Antioxid Redox Signal 9:553-561. https://doi.org/10.1089/ars. 2006.1524

65. Cole NB, Dieuliis D, Leo P, Mitchell DC, Nussbaum RL (2008) Mitochondrial translocation of alpha-synuclein is promoted by intracellular acidification. Exp Cell Res 314:2076-2089. https://doi. org/10.1016/j.yexcr.2008.03.012

66. Liu G, Zhang C, Yin J, Li X, Cheng F, Li Y, Yang H, Uéda K et al (2009) alpha-Synuclein is differentially expressed in mitochondria from different rat brain regions and dose-dependently down-regulates complex I activity. Neurosci Lett 454:187-192. https://doi.org/ 10.1016/j.neulet.2009.02.056

67. Seo JH, Rah JC, Choi SH et al (2002) Alpha-synuclein regulates neuronal survival via Bcl-2 family expression and $\mathrm{PI} 3 /$ Akt kinase pathway. FASEB J 16:1826-1828. https://doi.org/10.1096/fj.020041 fje

68. Su Y, Duan J, Ying Z, Hou Y, Zhang Y, Wang R, Deng Y (2013) Increased vulnerability of parkin knock down PC12 cells to hydrogen peroxide toxicity: the role of salsolinol and NM-salsolinol. Neuroscience 233:72-85. https://doi.org/10.1016/j.neuroscience. 2012.12.045

69. Yang H, Zhou HY, Li B, Niu GZ, Chen SD (2007) Downregulation of parkin damages antioxidant defenses and enhances proteasome inhibition-induced toxicity in PC12 cells. J NeuroImmune Pharmacol 2:276-283. https://doi.org/10.1007/s11481-007-9082-2

70. Oluwatosin-Chigbu Y, Robbins A, Scott CW, Arriza JL, Reid JD, Zysk JR (2003) Parkin suppresses wild-type $\alpha$-synuclein-induced toxicity in SHSY-5Y cells. Biochem Biophys Res Commun 309: 679-684. https://doi.org/10.1016/j.bbrc.2003.08.059

71. Petrucelli L, O'Farrell C, Lockhart PJ, Baptista M, Kehoe K, Vink L (2002) Parkin protects against the toxicity associated with mutant alpha-synuclein: proteasome dysfunction selectively affects catecholaminergic neurons. Neuron 36:1007-1019. https://doi.org/10. 1016/s0896-6273(02)01125-X 